\title{
Housing equity withdrawal for development of assisted-living facilities
}

\author{
David Bogataj \\ Department of Management and Engineering, University of Padua, Padua, Italy \\ Valerija Rogelj \\ CERRISK, Institute INRISK, Trebnje, Slovenia \\ Marija Bogataj \\ Department of Economics and Business, University of Ljubljana, \\ Ljubljana, Slovenia, and \\ Eneja Drobež \\ Department of Civil and Commercial Law, European Faculty of Law, \\ New University, Nova Gorica, Slovenia
}

\begin{abstract}
Purpose - The purpose of this study is to develop new type of reverse mortgage contract. How to provide adequate services and housing for an increasing number of people that are dependent on the help of others is a crucial question in the European Union (EU). The housing stock in Europe is not fit to support a shift from institutional care to the home-based independent living. Some $90 \%$ of houses in the UK and $70 \%-80 \%$ in Germany are not adequately built, as they contain accessibility barriers for people with emerging functional impairments. The available reverse mortgage contracts do not allow for relocation to their own adapted facilities. How to finance the adaptation from housing equity is discussed.
\end{abstract}

Design/methodology/approach - The authors have extended the existing loan reverse mortgage model. Actuarial methods based on the equivalence of the actuarial present values and the multiple decrement approach are used to evaluate premiums for flexible longevity and lifetime long-term care (LTC) insurance for financing adequate facilities.

Findings - The adequate, age-friendly housing provision that is appropriate to support the independence and autonomy of seniors with declining functional capacities can lower the cost of health care and improve the well-being of older adults. For financing the development of this kind of facilities for seniors, the authors developed the reverse mortgage scheme with embedded longevity and LTC insurance as a possible financial instrument for better LTC services and housing with care in assisted-living facilities. This kind of facilities should be available for the rapid growth of older cohorts.

Research limitations/implications - The numerical example is based on rather crude numbers, because of lack of data, as the developed reverse mortgage product with LTC insurance is a novelty. Intensity of care and probabilities of care in certain category of care will change after the introduction of this product.

(C) David Bogataj, Valerija Rogelj, Marija Bogataj and Eneja Drobež. Published by Emerald Publishing Limited. This article is published under the Creative Commons Attribution (CC BY 4.0) licence. Anyone may reproduce, distribute, translate and create derivative works of this article (for both commercial and non-commercial purposes), subject to full attribution to the original publication and authors. The full terms of this licence may be seen at http://creativecommons.org/licences/by/4.0/legalcode

The authors acknowledge the project development of social infrastructure and services for community-based LTC, J6-9396 was financially supported by the Slovenian Research Agency.

Received 23 October 2018 Revised 4 September 2019 18 February 2020 Accepted 12 May 2020

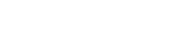


Practical implications - The model results indicate that it is possible to successfully tie an insurance product to the insured and not to the object.

Social implications - The introduction of this insurance option will allow many older adult with low pension benefits and a substantial home equity to safely opt for a reverse mortgage and benefit from better social care.

Originality/value - While currently available reverse mortgage contracts lapse when the homeowner moves to assisted-living facilities in any EU Member State, in the paper a new method is developed where multiple adjustments of housing to the functional capacities with relocation is possible, under the same insurance and reverse mortgage contract. The case of Slovenia is presented as a numerical example. These insurance products, as a novelty, are portable, so the homeowner can move in own specialised housing unit in assisted-living facilities and keep the existing reverse mortgage contract with no additional costs, which is not possible in the current insurance products. With some small modifications, the method is useful for any EU Member State.

Keywords Pension, Portfolio optimisation, Facilities for LTC, Housing rights, Longevity risk, Reverse mortgage

Paper type Research paper

\section{Introduction}

\subsection{The motivation for this article}

In the European Union (EU), currently, 40 million older people depend on the help of others. This number will increase to 55 million in 40 years. More than 4 million dependent older adults live in segregated residential institutions that are not able to guarantee personcentred services to achieve the total inclusion of the elderly in the community. According to The Ageing Report 2015 (European Commission, 2015a, 2015b), the number of dependent older adults will double by 2060. Human dignity and respect for human rights guide European Member States to implement the deinstitutionalisation of long-term care (LTC) systems. According to Principle 18 of the European Pillar of Social Rights on LTC "everyone has the right to affordable LTC services of good quality, in particular home-care and community-based services. Following also the provisions of the Convention on the Rights of Persons with Disabilities (United Nations, 2006) and the European Convention on Human Rights (Council of Europe, 1950), European member states must implement measures that strengthen the transition from an institutional to community-based facilities and services. As stated by the Innovation Union [European innovation partnership on Active and Healthy Ageing (EIP on AHA), 2015]:

[...] the building stock in Europe today is not fit to support a shift from institutional care to the home-based independent living model. Some 70-80 per cent of houses in the UK and 90 per cent in Germany are not suitable for independent living as they contain accessibility barriers for people with emerging functional impairments and chronic conditions.

This deinstitutionalisation procedure requires building new facilities for the elderly and remodelling their homes to adapt them to people with declining functional capacities and to organise a new logistic network in an accurately determined functional region (Drobne and Bogataj, 2014, 2015, 2016; Szander et al., 2017). We need to develop a sufficient number of the following care facilities:

- Independent living communities;

- Assisted-living facilities;

- Residential care facilities;

- Continuing care communities; and

- Nursing Homes (NHs), to provide the assistance and care of people who depend on the help of others and whose functional abilities are decreasing. 
For different levels of functional capacity of the elderly, various facilities are needed. The burden of investment lies mainly with local communities, but the taxes and other social assets are not sufficient to meet the needs of the elderly (Janež et al., 2016).

Life expectancy in Europe is increasing but expected healthy years are not following an increase in life expectancy. How to provide quality services and housing for an increasing number of people that are dependent on the help of others is a crucial question in the EU. By the »operational programme for the implementation of the European Cohesion Policy for the period 2014-2020«, as a critical area, Slovenia identified promoting the availability of affordable, sustainable and high-quality services, including health and social services of general interest also for old inhabitants. These services include LTC. Slovenian National housing programme 20152025, prepared by the Ministry of the environment and spatial planning envisioned the development of assisted-living facilities with 10,000 housing units. The programme also states that there are currently no financial resources allocated for the development of these facilities. In the paper, we present a model for financing the construction of assisted-living housing units with a current equity of senior homeowners, which are dependent on the help of others. The critical issue is how to develop a quantitative model for measuring and forecasting a long-term demand for LTC services and facilities for the elderly and how to plan and finance the assisted-living facilities for seniors with declining functional capacities, which will be available by the demand.

\subsection{Reverse mortgage in the Web of Science literature}

The reverse mortgage is a type of home loan that allows a borrower to open a line of credit while using his home as collateral. With the loan model, the beneficiary draws liquid amounts in lump-sum or/and periodically from the value of the real estate (VRE) in the form of a loan secured by a mortgage on the real estate. With the part of this liquid amount that is drawn from the real estate, the beneficiary purchases deferred lifetime annuity in the form of a monthly (or yearly) premium (PR).

The novelty in this paper is the inclusion of LTC insurance that covers expenditure for care when a person becomes dependent on the help of others. In this way, the beneficiary insures his longevity so that if he lives longer than his life expectancy and LTC expenditures that is contingent on the category of needed care when he becomes dependent on the help of others, he will receive a lifetime annuity until his death. In the paper, we propose the reverse mortgage model with the insurance for longevity, where the periodic disbursement that the beneficiary receives is the difference between the amount drawn and the annuity PR for longevity insurance. In this way, if the beneficiary survives the drawing period of a reverse mortgage ( $n$ years), he receives a lifetime annuity that covers the disbursement to the recipient and the interest on the outstanding loan. This is a new scheme, first proposed in Bogataj (2013a, 2013b) and now developed further. Generally, loan models allow the beneficiary to draw the VRE in different ways:

- In lump sum - at the closing of the reverse mortgage contract;

- In the form of a line of credit so that he can draw it when necessary; and

- In uniform periodic amounts in the period of life expectancy.

The model could belong to the set of models considering equilibrium in competitive insurance markets In case of imperfect information (Rothschild and Stiglitz, 1976), but the list of articles in Web of Science (WoS) dealing with the topic "asset-based policies" goes back only to 1995 and their number grows very slowly as given in Table 1, while the list of articles also dealing with "home-ownership" is shorter; there are only 30 papers in WoS. Rasmussen et al. (1997, electronic version 2010) were considering the reverse mortgage as an 
asset management tool at the end of the past century. Unlocking housing equity through reverse mortgages was developed in Australia already in the first decade of this century (Ong, 2008; Davis, 2009). First, four papers on homeownership in WoS were published in 2009 and there is no growth of intensity. However, among articles dealing with "asset-based policies" and "equity release" we found only eight items in WoS while there are only two papers in the WoS Core Collection dealing with "asset-based policies" and "reverse mortgage (Bogataj, 2013a, 2013b; Haffner et al., 2015). Haffner et al. investigated whether there are links between institutional context and the development of markets in home equity conversion that are based on financial instruments facilitating mortgage equity withdrawal. Based on the secondary data and literature review considering four older EU member states, USA and Canada. They exposed that there are, in principle, three channels of housing equity withdrawal in the developed countries, namely:

(1) mortgage equity withdrawal;

(2) trading on where owners move from one dwelling to another but hold a lower amount of housing equity in the home they purchase; and

(3) selling up.

As their countries in the investigation had similar per capita GDPs, therefore, at the same stage of economic development, from their paper, it is not clear what are possibilities in less developed countries. They also refer to Doling and Ronald (2010b) on "property-based welfare and European homeowners: How would housing perform as a pension", where a significant positive correlation between before-housing poverty rates among over $65 s$ and the rates of homeownership in a sample of EU countries has been proved. Haffner et al. also exposed tax rules, which can also deter or incentivise mortgage equity withdrawal. They have not even overlooked the fact of exposure to the risk of various mortgage equity withdrawal programmes such as in the USA, where now the Home Equity Conversion Mortgage insurance, provided by Housing and Urban Department of US Government, ensures that reverse mortgages that are offered to homeowners 55+ years old are affordable and the reverse mortgage legislation stipulates that the products are safe and reliable for users.

However, Haffner and al. concluded that "it is conceivable that unmeasured cultural or other differences exist that might also be responsible for the evolution of mortgage equity withdrawal in each country". In the welfare systems of Souther European countries have traditionally been met more by the family, according to our investigation, especially in rural areas, the elderly are primarily taken care of by families (Bogataj et al., 2016). Practices of intergenerational support for homeownership among different generations of families are also described in Manzo et al. (2019), where they stressed the role of homes and housing assets in mediating dependence and re-affirming family ties and relationships.

The welfare systems of Eastern European Countries have usually been achieved by state social protection measures and by the family, while the ownership structure has been dramatically changed after the transition in the nineties, after the privatisation of public housing and reduction of public social housing (Bogataj, 2013a, 2013b; Mandič, 2010). After the intensive research of East Asian cases, Doling and Ronald (2012) wrote that:

Table 1.

The list of articles in WoS dealing with the topic "asset-based policies"

\begin{tabular}{ccccc}
\hline 1995 & $2000-2004$ & $2005-2009$ & $2010-2014$ & $2015-2019$ \\
\hline 1 & 28 & 22 & 30 & 55 \\
\hline
\end{tabular}


[. . .] in the welfare systems of East Asian countries, the income, care and other needs of older people have traditionally been met less by state social protection measures and more by the family, supported by what might be termed the first homeownership strategy: widening access to home ownership as a physical, emotional and financial basis of family wellbeing.

Equity release schemes (ERS) fall under the list of instruments that support the asset-based welfare of the older adults for their assets rather than their pensions. Asset-based welfare bases on the stock of capital that one holds and not just his yearly income.

Asset-based welfare is based on the statements that an economy can achieve a path towards prosperity if the individuals accumulate and acquire assets. According to Paxton's theory, the stock of capital is the real measure of well-being. The asset-based approach to welfare provision is a theoretical model based on the theoretical assumption that housing is a good that enables the flow of other household goods and services and the "pillar under the welfare state" (Torgersen, 1987; Malpass, 2008) or "cornerstone of welfare" (Doling and Roland, 2010a, 2010b; Ronald and Doling, 2012). The theory is spreading from the UK to some other countries and is leading to a more market-oriented housing policy (Ronald and Doling, 2012). Risk individualisation through asset creation is also prevalent in post-socialist transition countries, as evidenced by the high levels of homeownership, as the ratio of owner-occupied units to total residential units in a specified area, after the privatisation of public housing and the dramatic reduction of public social housing (Mandič, 2010).

The details in 2013 and 2014 are given in Table 2. Homeownership rates have declined after the financial crisis in many countries, particularly in South-Europe, but in Eastern European countries not so much. There most of the properties are mortgage-free because of the national privatisation programmes in the nineties.

\subsection{The structure of this article}

As housing is an essential component of welfare strategies for homeowners (Soaita et al., 2017), for the ageing societies, which are subject of our investigation, we join the advice that housing wealth would be an excellent asset to be withdrawn to compensate for reduced income after retirement (De Decker and Dewilde, 2010; Malpass, 2008, Bogataj and Bogataj, 2015, Bogataj et al., 2016) and essential for the LTC provision. Thus, the objective of the

\begin{tabular}{|c|c|c|c|c|c|c|}
\hline Country & 2013 & 2014 & Country & 2013 & 2014 & \\
\hline Romania & 95,6 & 96,2 & Cyprus & 74,0 & 72,9 & \\
\hline Lithuania & 92,2 & 89,9 & Finland & 73,6 & 73,2 & \\
\hline Slovakia & 90,5 & 90,3 & Italy & 73,3 & 73,1 & \\
\hline Hungary & 88,7 & 88,2 & Luxembourg & 73,0 & 72,5 & \\
\hline Croatia & 88,5 & 89,7 & Belgium & 72,3 & 72,0 & \\
\hline Bulgaria & 85,7 & 84,3 & $\mathrm{EU}-28$ & 70,0 & 69,9 & \\
\hline Poland & 83,8 & 83,5 & Ireland & 69,9 & 68,6 & \\
\hline Norway & 83,5 & 84,4 & The Netherlands & 67,1 & 67,0 & \\
\hline Latvia & 81,2 & 80,9 & Euro area & 66,5 & 66,7 & \\
\hline Estonia & 81,1 & 81,5 & Sweden & 66,3 & 65,6 & \\
\hline Malta & 80,5 & 79,8 & UK & 64,6 & 64,4 & \\
\hline Czechia & 80,1 & 78,9 & Denmark & 64,5 & 63,3 & \\
\hline Spain & 77,7 & 78,8 & France & 64,3 & 65,0 & Table 2. \\
\hline Iceland & 77,5 & 78,2 & Turkey & 60,7 & 61,1 & The homeownership, \\
\hline Slovenia & 76,6 & 76,7 & Austria & 57,3 & 57,2 & as the ratio of owner- \\
\hline Greece & 75,8 & 74,0 & Germany (FRG) & 52,6 & 52,5 & occupied units to \\
\hline Portugal & 74,2 & 74,9 & Switzerland & 44,0 & 44,5 & total residential units \\
\hline
\end{tabular}

\section{Housing equity withdrawal}

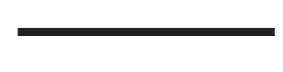


paper is to present how to develop an actuarial model for determining the capacities for LTC in different types of facilities in the system. Therefore, after discussing the right to suitable accommodation as the human right in Paragraph 2 and the presentation of specialised housing for older adults in Paragraph 3, in Paragraph 4 the data collection is discussed. The article also presents the proposal for a model of collecting and processing data in the system of statistical reports relevant for the whole country, to better forecast the long-term needs of facilities for seniors with declining functional capacities. In Paragraph 5, we have extended the existing loan reverse mortgage model presented in Bogataj (2013a, 2013b) and Bogataj and Bogataj, 2015. The challenge is EU-wide, but the numerical example is given for Slovenia. The probabilities are derived from the data provided by the Slovenian institutions. The general formula can be useful for any EU member state. In all EU Member States, the LTC is provided according to the categories of care but the number of categories is varying from 3 to 7 . Actuarial methods based on the equivalence of the actuarial present values and the multiple decrement approach we further developed to evaluate PRs for flexible longevity and lifetime LTC insurance for financing adequate facilities. Our studies show that currently available reverse mortgage contracts lapse when the homeowner moves to assisted-living facilities in any EU Member State, while in our article a new method is developed where multiple adjustments of housing to the functional capacities with relocation is possible under the same insurance and reverse mortgage contract. For a numerical example, we have calculated the case of Slovenian reverse mortgage programme in Paragraph 5.4. After the discussion in Paragraph 6, we suggested conclusions and directions to further research.

\section{Right to suitable accommodation and assisted-living facilities in the constitutions and international norms}

The primary need of human beings is housing. It involves shelter for survival and protection of human dignity (Drobež and Bogataj, 2016), merely a place to live in the home, giving a sense of personal space. Adequate and appropriate housing constitutes the core of housing rights. When an older person loses his/her functional capacities, the adequacy of the home is reduced and when an older adult leaves his/her home and relocates to the institutional care, some critical dimensions of these rights are lost. Such institutions were created to provide care, food and shelter, but by now evidence has shown that they cannot ensure personcentred facilities and services and appropriate support according to the needs of an individual aged person. Securing the rights of seniors with declining functional capacities to integrity and independence is substantially reduced when they move from communitybased facilities to the institutional LTC (Drobež and Bogataj, 2016). In its recent documents, the EU recommends to start the process of deinstitutionalisation of residential NHs and to develop community-based facilities and services for senior citizens. International, European and national sources of law oblige EU Countries to conduct deinstitutionalisation. In this respect also a particular emphasis on human rights issues should be considered. When considering the development of LTC system Slovenia and other EU member states should abide by the requirements of the European Social Charter and the European Charter of Fundamental Rights, which entail the rights of elderly persons to choose their life-style freely and to lead independent lives. In some EU Countries, like in Slovenia, the Constitutions do not provide for a particular article on the rights of seniors. We believe that special consideration should be made for elderly with declining functional capacities, and thus, depended on the help of others, when their human rights are at stake, also in the context of the right to appropriate housing (like in Article 78 of Slovenian Constitution). This right belongs to the catalogue of social rights, which do not operate by universally recognised minimum standards, and therefore, their vagueness and flexibility could affect 
their effectiveness. However, because of the vulnerability of seniors with declining functional capacities, unsuitable housing conditions could also result in a breach of their civil rights such as personality and privacy rights. The absence of proper actions of states could result in the breach of constitutional commitments (Drobež and Bogataj, 2016).

In an ageing society, which brings new challenges, how to organise the life and the lives of the elderly, new legal rules should be created. This requirement includes, in particular, the rules governing the financing of older adults, not only their health services but also proper facilities and assistance for them, as detailed in Margolis (2015). In the debates on policies for the elderly, new questions arise regarding the freedom of the individual, his autonomy and equality. Requirements for freedom and autonomy are the reasons why initiative for comprehensive constitutional protection of the rights of the elderly was born and is connected with the general rights to dignity. The study is proved in more detail as the most important for the elderly (Black and Dobbs, 2013, 2015; Park et al., 2013), but the basis for ensuring these rights makes the possibility for older adults to live in a suitable dwelling and age-friendly environment. The issue of the legally protected right to adequate housing for older people has become especially important in some European countries after the Council of the EU recommended that they should go into the process of deinstitutionalisation. It is assumed that there will be improved access to services by shifting LTC from institutional care to elderly homes home-care, (see for example, the Council Recommendations of 9 July 2013 on the National Reform Programme for Slovenia for 2013 and the opinion of the Council of the Stability Programme of Slovenia for the period 2012-2016 (Council of Europe, 2013, Paragraph 2). However, for successful deinstitutionalisation, it will not be enough to move back or to retain older citizens with declining functional, physical and cognitive capacities for a more extended period in the previous home environment. It also requires to adapt homes and develop housing with care $(\mathrm{HwC})$ and lifetime neighbourhood that can accommodate older adults or replace it with a more appropriate one. The real estate market and the legal profession and especially the legislative and executive branches, must respond to this challenge. Many of national acts of the developed world define and enact at least four accessibility features to be included in new homes and have a significant impact on accessibility for people with declining functional abilities and consequently for the wider community. These features include a clear street way (including a suitable parking area), entry without stairs and other obstacles, larger door openings and passes, access to a toilet suitable for people with reduced mobility at the entrance level and reinforcement of the walls of the bathroom (Department of Planning and Community Development, 2010; PARA, 2006). Countries and local communities further sharpen these requirements, as can be seen from some legal documents (Seekins et al., 2008; Canadian Centre on Disabilities Studies, 2014; Ward and Franz, 2015; Rogers et al., 2015; Nasar and Elmer, 2016).

\section{Assisted living facilities for older adults with declining functional capacities} Most of the senior residents would like to age in the community (EC, 2007). Research in Slovenia has shown that most of the older homeowners understand that they will not be able to stay safe and healthy in their own home due to declining functional capacities and would prefer to move to a housing unit in assisted-living facilities instead of to a NH (Kavšek and Bogataj, 2016).

To determine the parameters of multiple decrements model in housing, primarily to determine the probabilities of transitions between different type of dwellings also, qualitative analyses like those done by Black and Dobbs (2013), Chapin et al. (2001), Chapin and Dobbs-Kepper (2001) are required. To compare the costs and capacities in EU and USA and to determine the best practice and planning, the papers of Daaleman et al. (2008), 
Temple et al. (2009, 2010) and Gordon et al. (2010) provide guidelines for our further research. Qualitative and mixed methods analyses as the ones developed by Debra Dobbs and other researchers (Black and Dobbs, 2013; Chapin, Dobbs-Kepper, Oslund, 2001; Chapin and Dobbs-Kepper, 2001; Daaleman et al., 2008) enable us to understand USA and European consumers of LTC services and why the numbers in EU and USA are not the same.

UK research (Wood, 2017) has shown that residents living in assisted-living facilities visit a general practitioner less frequently, have much shorter average hospital stays, the much lower probability of falls and hip fracture and a smaller percentage of them suffer from loneliness. This has been apparent from several studies (Berrington, 2017; Fiel et al., 2002) and is influencing the development of housing policy in the UK as reflected in the official inquiry of Work and Pension Committee, (UK Parlament, 2017). Until the past decade, a critical view of the meaning and potential role of housing in community care has remained mostly absent from the scientific debate. Ageing of the population requires specific dynamics in the development of the age-friendly environment. The built environment should be better adapted to the ageing population. Feeling secure in one's living environment strongly a ects people's willingness to move about in the local community, which, in turn, a ects their independence, physical health, social integration and emotional well-being. (Kalache and Plouffe, 2007). According to the ageing report, 2018 more than $30 \%$ of Europeans will be 65 or older. Most of them will be living in single households. Therefore, they will occupy a large part of the housing stock.

Housing stock currently is not suitable for persons with declining functional capacities because of barriers to build environment. In the next 50 years, at least $30 \%$ of the built environment will need to be modified to accommodate people with declining functional capacities, which need safer and housing units and more amenities. These dynamics will pressure the public finances for investment in assisted-living facilities, hospitals for servicing seniors and other public buildings. The Ageing Report 2018 (EC, 2018a) is providing the basis for the projections of the needed structure of assisted-living facilities in the European countries. Housing is a potential source of both material and environmental well-being (Costa-Font, 2013; Rossi and Weber, 1996; Rohe et al., 2001). According to research done by Institut national de la statistique et des études économiques (www.insee.fr), more than $70 \%$ of senior citizens $60-80$ years old live in owner-occupied housing. In the countries with low pension income such as Slovenia, Croatia, Spain and other Southern and Eastern EU countries, this home-ownership rate among senior citizens is over 80 and has been increasing in the recent 40 years substantially. It means that seniors are income poor and asset rich. The problem is that there are not developed flexible financial mechanisms to tap this accumulated wealth and use it to adapt their homes to their declining functional capacities and also enable relocation to assistedliving facilities when the decline in functional abilities of homeowner requires it.

Using actuarial mathematics, developing further the life contingencies, the paper will present how reverse mortgage systems with the embedded insurance for longevity and LTC might allow residents with declining functional capacities to stay in the community longer and delay or even prevent moving to the $\mathrm{NH}$.

\section{Development of statistical research in the field of long-term care}

\subsection{Measuring the care dependency in European Union}

Statistical monitoring of the number of beneficiaries and the financing of LTC is a crucial base for the efficient and effective planning of spatial capacities and necessary human resources for carrying out LTC activities. The data are scattered across many institutions and sources. Preferences of Europeans for LTC provision are presented by Eurobarometer 283 (EC, 2007). Population projections for the European population for period 2018-2020 were made by 
EUROSTAT (Eurostat, 2018) and Budgetary projections for the period 2016-2070 are published in The Ageing report 2018 (EC, 2018a). Systematic reviews of organisations of LTC provision and LTC funding by some European and other countries are presented in the study of European Commission "challenges in LTC in Europe: A study of national policies" (Spasova, et al., 2018). In Europe, the issue of LTC has already been addressed by the European Commission (2010) and later by Ujvari (2012) and Bocquaire (2016).

In EU Member states the public LTC provision could be wholly or partly financed through health insurance schemes, LTC insurance schemes and state budgets). Eligibility for partially publicly funded LTC services can be subject to care needs of the dependent person, his or her income and assets and the availability of family carers. For assess the care needs, a home visit is usually carried out by the social services but the statistics on needs are not available for planning purposes. The assessment of care needs is increasingly based on a functional assessment, using a scale defining the degree of care dependency.

The system of LTC provision in England has 4 categories of care where care needs are defined as (I. - critical, II. - crucial, III. - moderate and IV . - Low) and presented by ComasHerrera et al. (2010). LTC system in Hungary has 8 categories of care as presented by Czibere and Gal (2010). Bulgaria has 3 categories of LTC (I. > 90\% dependent, II. In total, $71 \%-90 \%$ dependent, III. In total, 50\%-70\% (Riedel and Kraus, 2010). LTC system in Austria has 5 categories of care according to the number of hours of care needed (I $>60 \mathrm{~h}$, II $>85 \mathrm{~h}$, III $>120 \mathrm{~h}, \mathrm{VI}>160 \mathrm{~h}, \mathrm{Va}, \mathrm{b}, \mathrm{c}>180 \mathrm{~h}$ per month). In Germany, the scale of dependency consists of four categories of LTC insurance I, II, III, III+, which depends on the number of hours of assistance and care needed, as described by Arntz et al. (2007) and Schulz (2010a, 2010b). System of LTC provision in Slovenia has 4 categories from the lowest needs (I) to the highest needs (IV) as presented by Rupel-Prevolnik and Ogorevc (2010) and Kavšek and Bogataj (2017). Category of care I-III can also be provided as homecare or in assisted living housing, but the LTC of category IV can only be provided in a NH.

One of the best-structured systems of LTC provisions is organised in Spain where they have 3 categories of care, each divided into two levels according to the need of user and number of hours of care as presented in Gutiérrez et al. (2010). Therefore, after examining the organisation of LTC across the EU Member States, we selected the Kingdom of Spain as a useful example of how to regulate the system of LTC provision and how to institute comprehensive information system for recording LTC users and services.

The care of the elderly is legally defined under the auspices of the Ministry of Health, Social Services and Equal Opportunities (Spanish Ministerio de Sanidad, Consumo y Bienestar Social, Servicios Sociales e Igualdad) under the following laws:

- The Act on the Promotion of Independence and Care of Persons Dependent on the Assistance of Others (Boletin Oficial del Estad, 2006);

- Act on the Rights of Persons with Reduced Functional Abilities and Their Social Inclusion (Boletin Oficial del Estad, 2013a);

- Royal Decree 174/2011, which sets the scale for assessing the ability of selfsufficiency or addiction (Boletin Oficial del Estad, 2011);

- Royal Decree 1050/2013, which places a range for evaluating the ability of autonomy or dependence (Boletin Oficial del Estad, 2013b); and

- Decision SSI/2371/2013, which regulates the information system for monitoring dependency on 18 December 2013 (Boletin Oficial del Estad, 2013a, 2013b).

The Act on the Promotion of Independence and Care for Persons Dependent on the Help of Others (2006) regulates the system of LTC. It provides a catalogue of essential services and 
benefits to which all citizens are entitled. The Act determines, which services are directly accessible in the community and for which the beneficiary receives cash benefits, sets the criteria for determining the amount of remuneration, the level of participation of the recipients in the cost of services and sets the scale for the assessment of functional capabilities. The law provides a system of assistance to achieve the maximum possible autonomy and care of people who are dependent on the help of others. (Bogataj et al., 2015). However, there is no unified information system to be able to measure the quality of services.

\subsection{Long-term care information system}

For the development of LTC insurance product embedded in reverse mortgage housing equity withdrawal, statistical data on LTC provision and needs and housing needs are of significant importance. LTC information system should record the following data of applicants and beneficiaries (Table 3):

For better support of spatial planning and timely investments in facilities for older inhabitants, also the detailed description of the current housing of seniors should be included in an information system. Such details would allow for better planning and development of proper assisted-living facilities.

The range of social services for care-dependent older people can vary widely between and within countries in terms of the care provided. Social care includes home care, semiresidential care and residential care. The services can be strongly intertwined with healthcare-related LTC services. Home care, first of all, assists in the activities of daily life (bathing, clothing, eating, shopping, cooking, etc.).

In Slovenia like in many other EU member states capacities of residential care in NHs do not satisfy the demand to provide room for all persons that applied for NHs. According to different sources of data, we can see that there were in Slovenia 17,783 NH residents older than 64 years at the end of 2016 according to data provided by National health insurance institute (ZZZS), 7,100 home care users at the end of 2015 according to information provided by Institute for social service provision of Republic of Slovenia as presented in the report of Nagode et al. (2014) and 6,417 applicants for NH according to Association of institutional care providers of Slovenia (SSZS). From data provided by Slovenian national health institute for 2016, we have calculated the probability that person in a cohort will be dependent on the help of others in a specified category of care.

Currently, we have available only yearly data regarding institutional care in the NHs, by age, gender and category of care from 1 to 3 . We have added to this data the number of persons in the home care and number applications for institutional care (Table 4). We have calculated the probabilities that the older adult is dependent on the help of others in a specified category of care.

According to the study of Nagode et al. (2015a, 2015b), there were 866 assisted-living housing units in Slovenia in the year 2014 and according to to the research done by authors till 2017, the number has increased to 933. A number of the owner-occupied assisted-living housing unit is 335 . According to data provided by SSZS, there were 20,602 beds in NHs in September 2017 in Slovenia. Currently, capacities in assisted-living facilities present less than $5 \%$ of capacities in NHs in Slovenia. The probability that an older person will be in a particular category of care in a $\mathrm{NH}$ and the probability that an older person will be dependent on the help of others and will need care in a specific category for male and female is presented in Table 5, while the category of care - probability matrix of the state of the system is given in Table 6 and the number of home care users from 1998 to 2015 in Table 7. 

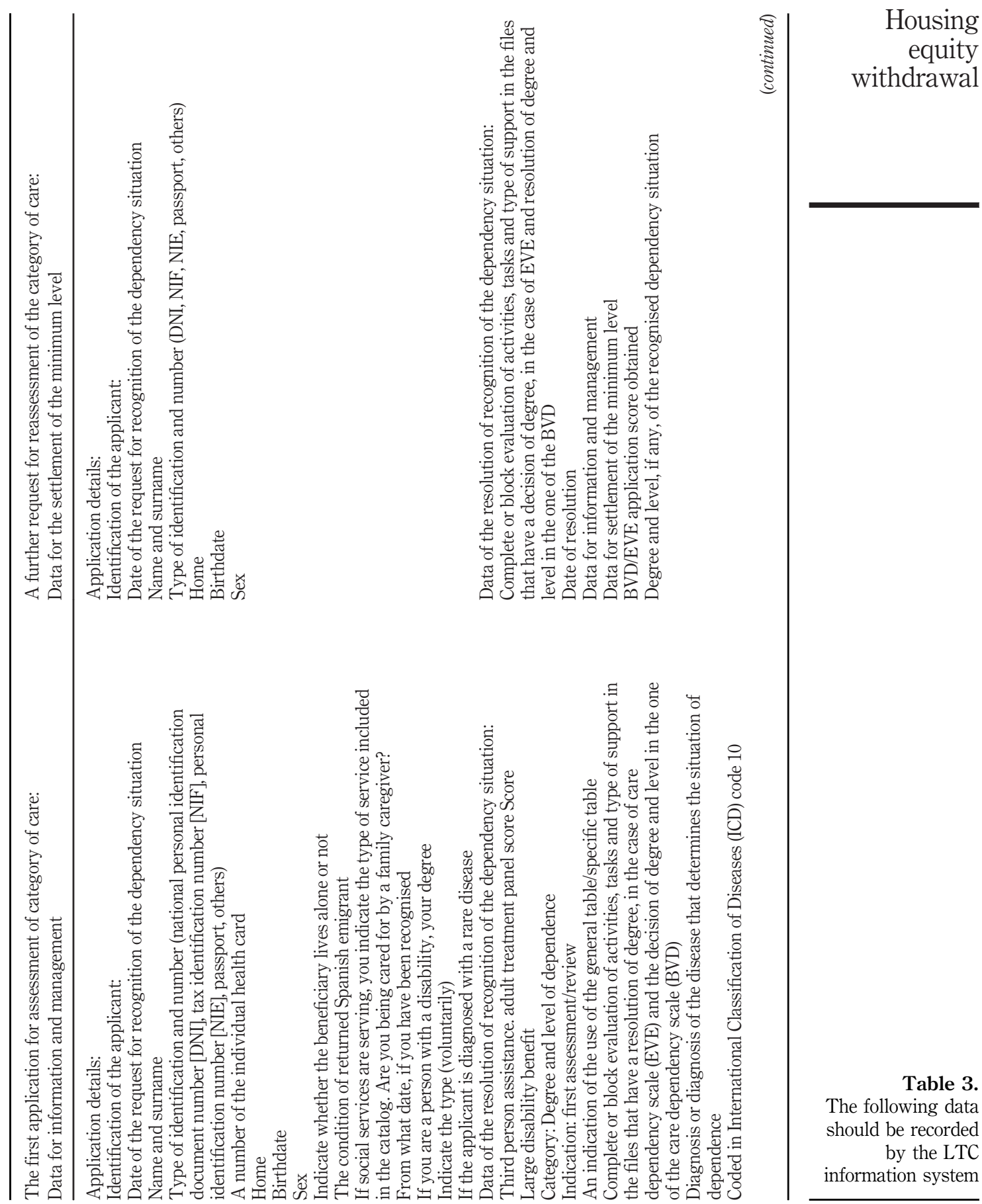

Table 3. The following data should be recorded by the LTC information system 


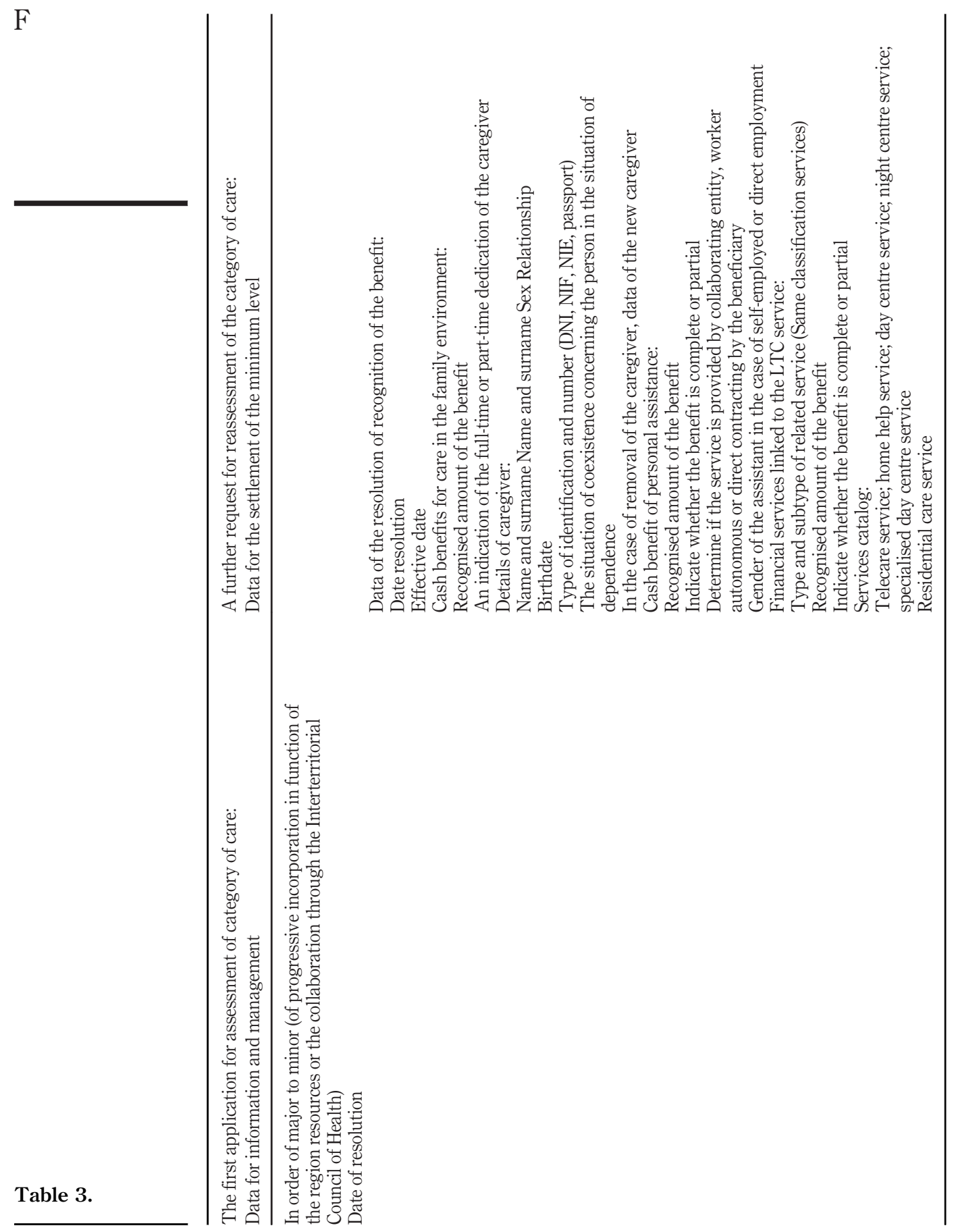




\section{Model}

\subsection{Actuarial model of long-term care insurance}

We will use the following notation and abbreviations:

$$
\begin{aligned}
& { }^{c} P_{x: h \mid}^{L T C} \quad-\text { yearly PR for LTC insurance for person } x \text { years old payable for } h \text { years (in the } \\
& \text { period of coverage, coverage starts at } \mathrm{x} \text { years of age); } \\
& { }^{b} P_{x: h \mid}^{L T C} \quad \text { - yearly PR for LTC insurance for person } \mathrm{x} \text { years old payable for } h \text { years (before } \\
& \text { the period of coverage, coverage for LTC claims starts at } \mathrm{x}+\mathrm{h} \text { years of age); } \\
& P_{x}^{L T C} \quad \text { - the single PR for LTC insurance for person } x \text { years old; } \\
& a(x)=a_{(x)} \text { - the present value of the lifetime annuity for } € 1 \text {, paid at the beginning of each } \\
& \text { yearfor the person that is } x \text { years old - according to the mortality table; } \\
& \text { LTCa }(x) \text { - the actuarial present value of lifetime expenditures for LTC services for person } \\
& x \text { years old; } \\
& \gamma_{2} \quad \text { - percentage of the administrative fee that insurance company charges at each } \\
& \text { payment of benefit; } \\
& \gamma_{1} \quad-\text { percentage of the administrative fee that insurance company charges at each } \\
& \text { payment of PR; } \\
& { }_{j} p_{x} \quad \text { - the probability that person } x \text { years old will survive } j \text { years; } \\
& p_{x}^{l t c(c a t)} \text { - the probability that person } x \text { years old is in the category of care [(cat)=I, II, III, IV]. } \\
& c_{\text {cat }}-\text { yearly expenditure on LTC services in the category of cat=I, II, III, IV. } \\
& v=\frac{1}{1+i} \text { interest factor where } I \text { is an interest rate. }
\end{aligned}
$$

\begin{tabular}{|c|c|c|c|c|c|}
\hline Independent & $\begin{array}{c}\text { Homecare users } \\
31.12 .2015\end{array}$ & $\begin{array}{c}\text { Applicants } \\
12.9 .2017\end{array}$ & $\begin{array}{c}\text { NHs residents } \\
31.12 .2016\end{array}$ & $\begin{array}{l}\text { Population in Slovenia } \\
2016\end{array}$ & \\
\hline $\begin{array}{l}\text { Male } \\
151,255\end{array}$ & 1,781 & 1,609 & 4,460 & 157,527 & \\
\hline $\begin{array}{l}\text { Female } \\
203,933\end{array}$ & 5,319 & 4,808 & 13,323 & 222,575 & $\begin{array}{r}\text { Table } 4 . \\
\text { Number of users and }\end{array}$ \\
\hline $\begin{array}{l}\text { Total } \\
355,188 \\
93.4 \%\end{array}$ & $\begin{array}{l}7,100 \\
1.9 \%\end{array}$ & $\begin{array}{l}6,417 \\
1.7 \%\end{array}$ & $\begin{array}{c}17,783 \\
4.7 \%\end{array}$ & $\begin{array}{c}380,102 \\
100.0 \%\end{array}$ & $\begin{array}{r}\text { applications of LTC } \\
\text { in Slovenia in 2017 } \\
\text { (age 65-100) }\end{array}$ \\
\hline
\end{tabular}

In the multi-state transition model with $m$ categories of the intensity of LTC provision for older adults with declining functional capacities, there are possibilities of $m+1$ transitions from one intensity of care to another. We denote the initial state (where the older adult is fully functional and does not need any care) as state 0 and transition, which require an intensity of care of type $j$ by the line of the graph from this parent node to the child node $j, j=$ $1,2, \ldots, m$. On this graph, we should describe the probabilities of transition from the state 0 and further states to the child node (state) $j \epsilon \mathrm{CC}$ or in general: from the parent node to the child node $\mathrm{j}$ at various ages. All paths to $\mathrm{j}$ determine the needed dynamics of development of community infrastructure for LTC provision with the number of serviced older adults in need of category of care of type j; it means the development of the required capacity of LTC provision of type $j$, which should be completed in a specific time $\tau$. In the multiple decrement model, transitions between any two states from $i$ to $j, i>j=1,2, \ldots, m$, are not possible (directed graph) (57).

An older adult can move among various states regarding their functional capacities and needed care. Let us consider an older adult $x$ denoted by $(x)$. We denote the future period in 


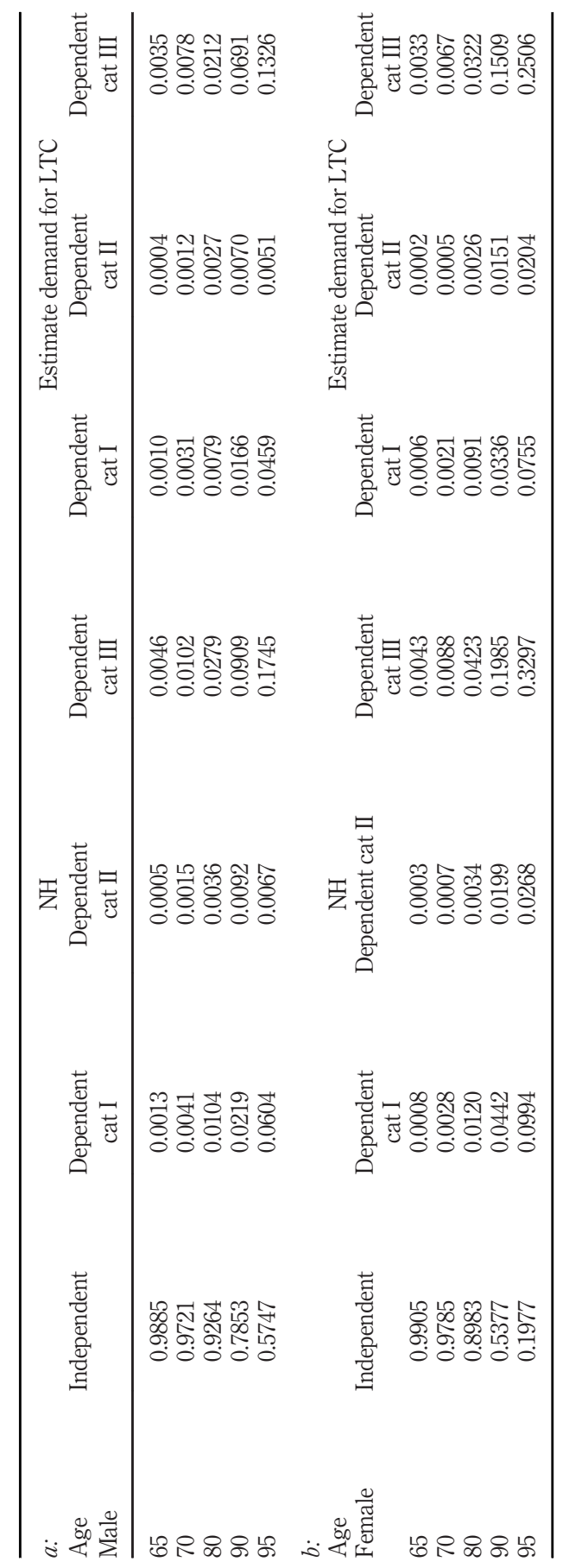

Table 5.

Probability that an older person will be in a particular category of care in $\mathrm{NH}$ and probability that an older person will be dependent on the help of others and will need care in a certain category for male (a) and female (b) 
which older adult will need the intensity of care in the category $i \in \mathrm{CC}$ by $\mathrm{T}_{i}(x)$. Thus, $x+$ $\mathrm{T}_{\mathrm{i}}(x)$ will be the age when the older adult because of declining in his functional capacities exits out of his or her current state $i$ and enters a new state where he will have to receive the intensity of care in category $j, j \in \mathrm{CC}$, which means a transit to a more intensive category of care of type $j$ or he exists the system due to death. The future period in which older adult will need the intensity of care in the category $i, \mathrm{~T}_{i}(x)$, is a random variable with probability distribution function:

$$
\mathrm{G}_{i}(t)=-\operatorname{Pr} \cdot\left(\mathrm{T}_{i} \leq t\right), t \geq 0
$$

The function $\mathrm{G}_{i}(t)$ represents the probability that the older adult will die or transfer to a more intensive category of care $\mathrm{j}$ (state $\mathrm{j}$ ) within $t$ years, for any fixed $\mathrm{t}$. We assume that $\mathrm{G} i(\mathrm{t})$, the probability distribution of $\mathrm{T} i$, is known. We also assume that $\mathrm{G}_{i}(\mathrm{t})$ is continuous and has probability density $g_{i}(t)=\mathrm{G}_{\mathrm{i}}^{\prime}(t)$. Data for $\mathrm{G}^{i}(t)$ should be available from national statistics. Thus, one can describe:

$$
\mathrm{g}_{i}(t) \mathrm{dt}=\operatorname{Pr}\left(t<\mathrm{T}_{i}<t+d t, j \in \mathrm{CC}\right)
$$

where (2) describes the probability that the older adult will transfer from the intensity of care in category $i$ (state $i$ ) in the infinitesimal time interval from $t$ to $t+d t$. Therefore, the probability that a worker aged $x$ in state $i$ will transfer into a state of type $j$ within $t$ years is denoted by the symbol ${ }_{t} q_{x}(i, j)$. We have, thus, the known relationship:

$$
{ }_{\tau} t q_{x}(i, y)=\mathrm{G}(i, j: t)
$$

Similarly, one can write:

$$
{ }_{t} p_{x}(i)=1-\mathrm{G}(i, j: t)
$$

\begin{tabular}{|c|c|c|c|c|c|c|c|c|c|}
\hline \multirow[b]{2}{*}{ Age } & \multirow[b]{2}{*}{$\begin{array}{l}\text { Indep- } \\
\text { endent }\end{array}$} & \multicolumn{3}{|c|}{ Male } & \multicolumn{4}{|c|}{ Female } & \multirow{7}{*}{$\begin{array}{r}\text { Table } 6 . \\
\text { Category of care } \\
\text { probability matrix of } \\
\text { the state of the } \\
\text { system }\end{array}$} \\
\hline & & $\begin{array}{l}\text { Dependent } \\
\text { cat I }\end{array}$ & $\begin{array}{l}\text { Dependent } \\
\text { cat II }\end{array}$ & $\begin{array}{l}\text { Dependent } \\
\text { cat III }\end{array}$ & $\begin{array}{l}\text { Indep- } \\
\text { endent }\end{array}$ & $\begin{array}{l}\text { Dependent } \\
\text { cat I }\end{array}$ & $\begin{array}{l}\text { Dependent } \\
\text { cat II }\end{array}$ & $\begin{array}{l}\text { Dependent } \\
\text { cat III }\end{array}$ & \\
\hline 65 & 0.9885 & 0.0024 & 0.0009 & 0.0082 & 0.9905 & 0.0014 & 0.0005 & 0.0076 & \\
\hline 70 & 0.9721 & 0.0072 & 0.0027 & 0.0180 & 0.9785 & 0.0049 & 0.0012 & 0.0155 & \\
\hline 80 & 0.9264 & 0.0182 & 0.0063 & 0.0491 & 0.8983 & 0.0211 & 0.0060 & 0.0745 & \\
\hline 90 & 0.7853 & 0.0385 & 0.0162 & 0.1600 & 0.5377 & 0.0779 & 0.0349 & 0.3494 & \\
\hline 95 & 0.5747 & 0.1063 & 0.0118 & 0.3071 & 0.1977 & 0.1749 & 0.0472 & 0.5802 & \\
\hline \multicolumn{2}{|l|}{ Year } & & & & & & & $\begin{array}{c}\text { Home care } \\
\text { users }\end{array}$ & \\
\hline & & & & & & & 3,909 & \\
\hline \multicolumn{2}{|l|}{2002} & & & & & & & 4,590 & \\
\hline \multicolumn{2}{|l|}{$\begin{array}{l}2004 \\
2007\end{array}$} & & & & & & & 4,732 & \\
\hline \multirow{2}{*}{\multicolumn{2}{|c|}{$\begin{array}{l}2007 \\
31.12 .2011\end{array}$}} & & & & & & & 5,595 & Table 7. \\
\hline \multirow{2}{*}{\multicolumn{2}{|c|}{$\begin{array}{l}31.12 .2011 \\
31.12 .2014\end{array}$}} & & & & & & & 6,624 & Number of the home \\
\hline & & & & & & & & 6,888 & care users from 1998 \\
\hline \multicolumn{2}{|c|}{31.12 .2015} & & & & & & & 7,100 & to 2015 in Slovenia \\
\hline
\end{tabular}

Equation (4) denotes the probability that a worker aged $x$ will remain in his or her current state at least $t$ years.
Housing equity withdrawal

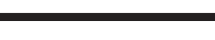


The transitions are successive according to the decline in functional capacities and the available intensity of care in the needed category. Let us denote: $i=0$ : fully functional older adult not in need of any care.

$i=1$ : the intensity of LTC is $0.5 \mathrm{~h}$ per day (LTC1);

$i=2$ : the intensity of LTC is $1 \mathrm{~h}$ per day (LTC2);

$i=3$ : the intensity of LTC is $1.5 \mathrm{~h}$ per day (LTC3); and

$i=4$ : the intensity of LTC is such that can only be provided in the NH(LTC4);

$i=5$ : functional capacities decrease to such a low level that older adults die (D).

Based on the data from the National Health Institute and Statistical Office, one can derive the expected needs of seniors at the national, regional or city/municipality level.

The probability $q_{x}^{(i, j)}$ that the functional capacities of the older adult that are currently receiving care in the category $i$ will decline in such extent that she/he will need the intensity of care in category $j$ for person $x$ years old is written by:

$$
q_{x}^{(i, j)}=\frac{M_{x}^{(i, j)}}{S_{x}^{(i)}} ; j=1,2,3,4 ; j>i
$$

Where $M_{x}^{(i, j)}$ is the number of older adults that transit from category $i$ to category $j$ and $L_{x}^{(i)}$ is the total number of older adults who were previously were receiving care in category $i-1$. Here $p_{x}{ }^{(i)}$ is the probability that the person is staying in the same category of care $i$. In the year $\tau$, the final structure of insured older adults by type of care needed for each person $x$ year-old in the cohort $\tau$ is described by the transition matrix (2). The basics of such transition are described in (58) and (59), only for the age - dependency structure:

$$
P_{x, \tau}=\left[\begin{array}{cccccc}
p_{x}^{(0)} & q_{x}^{(0,1)} & q_{x}^{(0,2)} & q_{x}^{(0,3)} & q_{x}^{(0,4)} & q_{x}^{(0,5)} \\
0 & p_{x}^{(1)} & q_{x}^{(1,2)} & q_{x}^{(1,3)} & q_{x}^{(1,4)} & q_{x}^{(1,5)} \\
0 & 0 & q_{x}^{(2)} & q_{x}^{(2,3)} & q_{x}^{(2,4)} & q_{x}^{(2,5)} \\
0 & 0 & 0 & q_{x}^{(3)} & q_{x}^{(3,4)} & q_{x}^{(3,5)} \\
0 & 0 & 0 & 0 & p_{x}^{(4)} & q_{x}^{(4,5)}
\end{array}\right]_{\tau}
$$

After such a transition in the year $\tau-1$, the structure of adapted homes needed by local older inhabitants is $L_{x, \tau}$ :

$$
L_{x, \tau}=L_{x-1, \tau-1} P_{x-1, \tau-1}
$$

The data should be available from the National Statistics Office. Currently, the data are not publicly available but are collected by the National Health Insurance Institute and not elaborated as needed for our planning the allocation of residents by type of facility in the year $\tau+1$ (when they are $x+1$-year-old) is:

$$
\begin{aligned}
& {\left[L_{x+1}^{(0)} L_{x+1}^{(1)} L_{x+1}^{(2)} L_{x+1}^{(3)} L_{x+1}^{(4)}\right]_{\tau+1} }= \\
& {\left[L_{x}^{(0)} L_{x}^{(1)} L_{x}^{(2)} L_{x}^{(3)} L_{x}^{(4)}\right]_{\tau} \cdot\left[\begin{array}{cccccc}
p_{x}^{(0)} & q_{x}^{(0,1)} & q_{x}^{(0,2)} & q_{x}^{(0,3)} & q_{x}^{(0,4)} & q_{x}^{(0,5)} \\
0 & p_{x}^{(1)} & q_{x}^{(1,2)} & q_{x}^{(1,3)} & q_{x}^{(1,4)} & q_{x}^{(1,5)} \\
0 & 0 & p_{x}^{(2)} & q_{x}^{(2,3)} & q_{x}^{(2,4)} & q_{x}^{(2,5)} \\
0 & 0 & 0 & p_{x}^{(3)} & q_{x}^{(3,4)} & q_{x}^{(3,5)} \\
0 & 0 & 0 & 0 & p_{x}^{(4)} & q_{x}^{(4,5)}
\end{array}\right]_{\tau_{\tau}} }
\end{aligned}
$$


The structure of the population of older adults according to the total needed intensity of care can be written as:

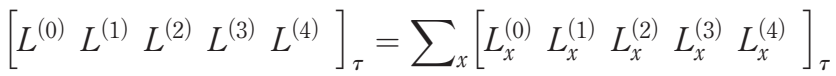

$$
\begin{aligned}
& \tau_{p_{x+j}}^{L T C 1}=\frac{\tau_{L_{x}^{(1)}}}{\tau_{L_{x}^{(0)}}+\tau_{L_{x}^{(1)}}+\tau_{L_{x}^{(2)}}+\tau_{L_{x}^{(3)}}+\tau_{L_{x}^{(4)}}} \\
& \tau_{p_{x+j}}^{L T C 2}=\frac{\tau_{L_{x}^{(2)}}}{\tau_{L_{x}^{(0)}}+\tau_{L_{x}^{(1)}}+\tau_{L_{x}^{(2)}}+\tau_{L_{x}^{(3)}}+\tau_{L_{x}^{(4)}}} \\
& \tau_{p_{x+j}}^{L T C 3}=\frac{\tau_{L_{x}^{(3)}}}{\tau_{L_{x}^{(0)}}+\tau_{L_{x}^{(1)}}+\tau_{L_{x}^{(2)}}+\tau_{L_{x}^{(3)}}+\tau_{L_{x}^{(4)}}}
\end{aligned}
$$

Actuarial present value as the present value of probability-weighted cash flows of expenditures for LTC services for an older adult who x-year-old in year $\tau$ is dependent on the help of others is:

$$
\tau_{L T C a_{(x)}}=\sum_{j=0}^{100-x}{ }_{j}^{\tau+j} p_{x} * \vartheta^{j} *\left({ }^{\tau+j} p_{x+j}^{L T C 1} * c_{1}+{ }^{\tau+j} p_{x+j}^{L T C 2} * c_{2}+{ }^{\tau+j} p_{x+j}^{L T C 3} * c_{3}\right)
$$

Insurance for covering expenditure for LTC services for a senior who is dependent on the help of others could be single or yearly PRs:

- The single PR for lifetime LTC for person $x$ years old in year $\tau$ :

$$
\begin{aligned}
P_{x}^{L T C} & =\left(1+\gamma_{2}\right) * L T C a_{(x)}=\left(1+\gamma_{2}\right) * \sum_{j=0}^{100-x}{ }_{j} p_{x} * \vartheta^{j} \\
& *\left({ }_{j} p^{\tau+j}{ }_{x+j}^{L T C 1} * c_{1}+{ }_{j} p^{\tau+j}{ }_{x+j}^{L T C 2} * c_{2}+{ }^{\tau+j} p_{x+j}^{L T C 3} * c_{3}\right)
\end{aligned}
$$

- Yearly PR for LTC insurance for person x years old in the year $\tau$, where the PR is payable $h$ years (coverage starts after $h$ years):

$$
\begin{gathered}
P_{x: h} L T C={ }_{j} p_{x} * \vartheta^{j} *\left(1+\gamma_{2}\right) * \frac{L T C a_{(x+h)}}{\left(1-\gamma_{1}\right) * \sum_{j=0}^{n-1}{ }_{j} p_{x} * \vartheta^{j}}= \\
\frac{{ }_{h}^{\tau} p_{x} k * \vartheta^{h *} *\left(1+\gamma_{2}\right) * \sum_{j=0}^{100-(x+h) \tau+j}{ }_{j} p_{x+h}+* \vartheta^{j} *\left({ }^{\tau+j} p_{x+h+j}^{L T C_{1}} * c_{1}+{ }^{\tau+j} p_{x+h+j}^{L T C_{1}} * c_{2}+{ }^{\tau+j} p_{x+h+j}^{L T C_{1}} * c_{3}\right)}{\left(1-\gamma_{1}\right) * \sum_{j=0}^{h-1} j^{\tau+j} p_{x} * \vartheta^{j}}
\end{gathered}
$$

- The PR for LTC insurance for person $x$ years old in the year $\tau$, at the closing of LTC insurance contract where the PR is payable $n$ years (coverage starts at age $x$ ): 


$$
P_{65: 16}^{L T C}=\left(1+\gamma_{2}\right) * \frac{L T C a_{(65)}}{\left(1-\gamma_{1}\right) * \frac{\vartheta^{n}-1}{\vartheta-1}}
$$

Actuarial formulas for calculation of PRs for longevity insurance presented in this chapter are for single life. Equations for joint life in the case that insurance would cove longevity of couple who own the property is presented in Gerber (1980).

\subsection{Numerical example of long-term care insurance for implementation in Slovenia}

Let us suppose that person dependent on the help of others needs the intensity of care as presented in Table 7 with the yearly expenditure for LTC - the social care as given in Table 8:

We will calculate the PR for the male, which will cover expenditures of LTC in the category of required care for a person who is dependent on the help of others:

- Mortality tables used for calculating annuity PR are the same as are prescribed by the Slovenian Agency for Insurance Supervision for calculating mathematical reserves (DAV 1994 R)

- The technical interest rate is $1.75 \%$, discount rate $=1 / 0.0175$ is

- Administrative costs $\gamma_{1}$ that insurance company charges in the period of payment of PR are $5 \%$ of the PR

- Administrative costs $\gamma_{2}$ that insurance company charges in the period of payment of benefits are $5 \%$ of the benefit paid.

- The probability that older adult is dependent on the help of others in a particular category of care was calculated from:

- data on LTC insurance (number of users by age, sex and category of care) for the year 2016 provided by National Health Insurance Institute and

- data on waiting list for residential care provided by Slovenian Association of Institutional Care Providers from April 2016.

- The data on expenditures for the social part of home-care (for one hour of home care per day - €16) was provided by Social Protection Institute of Slovenia and is the same as the average in 2016.

- The intensity of care used in Categories of care is $0.5 \mathrm{~h}$ per day for the category I, $1 \mathrm{~h}$ per day for the category II and $1.5 \mathrm{~h}$ per day for the category III.

The PR P $P_{25: 40 \mid}^{L T C}$ for LTC annuity with the actuarial present value $L T C a_{65}$ in an $L T C$ insurance scheme where contributions are paid for 40 years and benefits are paid from age 65 when a person becomes dependent on the help of others:

Table 8.

Yearly expenditure

for LTC - social care

\begin{tabular}{lccccc}
\hline Category & $\begin{array}{c}\text { Intensity of care } \\
\text { hours per day }\end{array}$ & $\begin{array}{c}\text { EUR } \\
\text { per hour }\end{array}$ & $\begin{array}{c}\text { Amount } \\
\text { per day } \\
\text { EUR }\end{array}$ & $\begin{array}{c}\text { Amount } \\
\text { per month } \\
\text { EUR }\end{array}$ & $\begin{array}{c}\text { Amount } \\
\text { per year } \\
\text { EUR }\end{array}$ \\
\hline I & 0.5 & 16 & 8 & 240 & 2,880 \\
II & 1.0 & 16 & 16 & 480 & 5,760 \\
III & 1.5 & 16 & 24 & 720 & 8,640 \\
\hline
\end{tabular}


- The single PR for lifetime LTC for a person 65 years old:

$$
\begin{aligned}
P_{65}^{L T C}= & \left(1+\gamma_{2}\right) * L T C a_{(65)}=\left(1+\gamma_{2}\right) * \sum_{j=0}^{100-65} j p_{65} * \vartheta^{j} \\
& *\left(p_{65+j}^{L T C 1} * c_{1}+p_{65+j}^{L T C 2} * c_{2}+p_{65+j}^{L T C 3} * c_{3}\right)=(1+0.05) * \sum_{j=0}^{100-65}{ }_{j} p_{65} * \vartheta^{j} \\
& *\left(p_{65+j}^{L T C 1} * 2,880+p_{65+j}^{L T C 2} * 5,760+p_{65+j}^{L T C 3} * 8.640\right)=5,363.46 * 1.05=5,631.64 €
\end{aligned}
$$

- Yearly PR for LTC insurance for a person 25 years old where the PR is payable 40 years:

$$
\begin{gathered}
P_{25: 40 \mid}^{L T C}=\frac{{ }_{40} p_{25} * \vartheta^{40} *\left(1+\gamma_{2}\right) * L T C a_{(65)}}{\left(1-\gamma_{1}\right) * \sum_{j=0}^{n-1} j p_{x} * \vartheta^{j}}= \\
=\frac{{ }_{40} p^{40} 25 * \vartheta^{40} *\left(1+\gamma_{2}\right) * \sum_{j=0}^{100-65}{ }_{j} p_{65} * \vartheta^{j} *\left(p_{65+j}^{L T C 1} * c_{1}+p_{65+j}^{L T C 2} * c_{2}+p_{65+j}^{L T C 3} * c_{3}\right)}{\left(1-\gamma_{1}\right) * \sum_{j=0}^{40-1} p_{x} * \vartheta^{j}}= \\
=\frac{{ }_{40} p^{40} 25 * \vartheta^{40} *\left(1+\gamma_{2}\right) * \sum_{j=0}^{100-65}{ }_{j} p_{65} * \vartheta^{j} *\left(p_{65+j}^{L T C 1} * 2,880+p_{65+j}^{L T C 2} * 5,760+p_{65+j}^{L T C 3} * 8.640\right)}{\left(1-\gamma_{1}\right) * \sum_{j=0}^{40-1} p_{x} * \vartheta^{j}} \\
=\frac{0.45001 * 0.49960 *(1+0.05) * 5,363.46}{(1-0.05) * 28.37712}=46.97 €
\end{gathered}
$$

- The PR for LTC insurance for a person 65 years old where the PR is payable for 16 years:

$$
P_{65: 16}^{L T C}=\frac{\left(1+\gamma_{2}\right) * L T C a_{(65)}}{\left(1-\gamma_{1}\right) * \frac{\vartheta^{n}-1}{\vartheta-1}}=420.64 €
$$

The numerical example is based on currently available data and the results are crude numbers due to lack of data. However, as in the numerical case the model is using observed patterns from the institutional care, which is reflecting not only demand (needs) but also supply, the probabilities of social care utilisation is expected to change because of change in behaviour of users of social care services and increase in procurement of services after introduction of reverse mortgage product.

\subsection{Optimal transitions among facilities}

An individual's independence and autonomy do not depend exclusively on his or her physical and cognitive abilities but also on the environment. The rate of functional decline is 
mainly dependent on and linked to the way of life and external social, environmental and economic factors.

Knowing the possible and desired options of older inhabitants to move in a housing unit in an assisted living facility, we shall model the demographic structure of population distributed among different types of facilities, and therefore, demand for new and more accommodative facilities.

The migrations need to be monitored and reported based on the functional capacities of residents. Figure 2 shows the graph of movements among different types of facilities, which will be under consideration. The notation in the diagram is the following (see the details in Bogataj et al., 2016):

We denote the initial state as state 0 and the decrement, which requires facility of type $j$ by the line of the graph from this parent node to the state (child node) $j, j=1,2, \ldots, m$. On this graph, we describe the probabilities of transition from the state 0 to further states to the child node (state) $j \epsilon H$ or in general: from the parent node to the child node $j$ at various ages. The probabilities depend on the age structure, functional capacities, preferences to move and the financial abilities and support networks of the potential users. All paths determine the needed dynamics for constructing the proper capacity of facilities of type $j$; it means inventories of different type of facilities in the process that should be completed at the time forecasted.

The transitions are successive according to the functional capacities, the available intensity of care and available facilities. We shall denote

$i=0$ : FH family home with fully functional and autonomous residents without the need for care;

$i=1$ : homecare in the adopted family home (adFH);

$i=2$ : housing unit in sheltered housing campus (SH);

$i=3$ : housing unit with available care services $(\mathrm{HwC})$; and

$i=4: \mathrm{NH}$;

$i=5 \operatorname{dead}(\mathrm{D})$.

We shall denote by $i$ the type of housing unit in which the resident is currently residing ( $i=0$ to 4 ); and by $j$ the type of housing unit to which the resident is moving due to declining functional capacity (resettlement from the type of facility $i$ to $j ; j=1$ to 5 ). The details of the migrations can be modelled as a directed graph in Figure 1, as simplified in Figure 2. Based

Figure 1.

Disability threshold and location of LTC provision

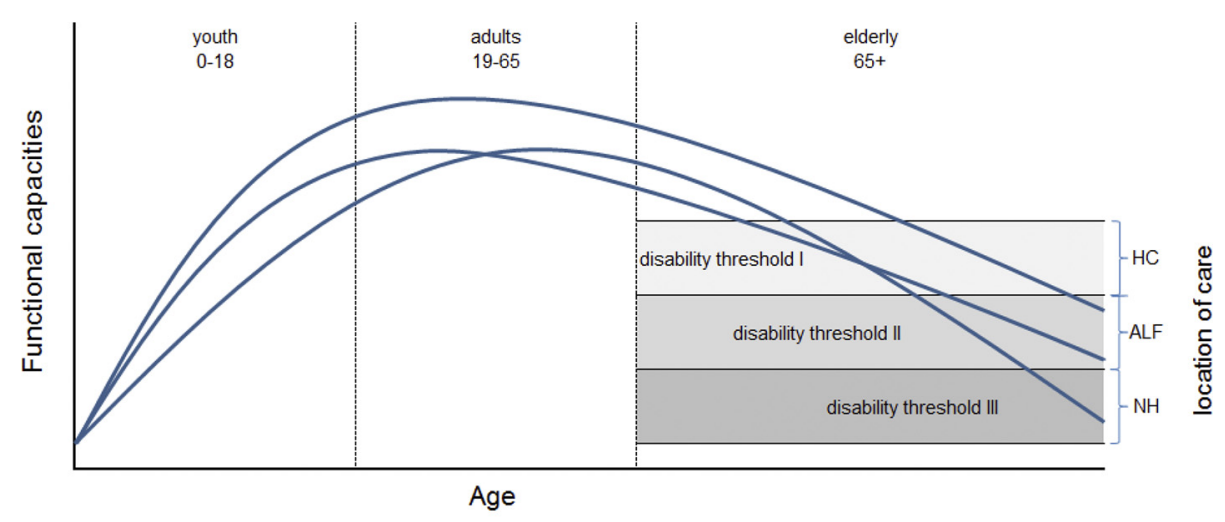

Notes: HC - home care; ALF - assisted living facilities; NH - nursing home 
on the demographic statistics, including the population's income, one can calculate the expected needs of older adults in the studied area and the probabilities of transitions among the different types of dwellings. Such transitions can be financed by personal insurance products, properly developed reverse mortgages schemes or based on national insurance schemes (Bogataj et al., 2015a, 2015b, 2016; Bogataj and Bogataj, 2015).

To successfully forecast the different accommodation needs of older adults - and therefore, the optimal structure of the facilities - based on the decreasing functional capacities of residents and the effective demand, we must know the probability distribution of ${ }^{\mathrm{F}} T_{i}(x)$, the time that an older adult will spend in the facility of type $i, i \in \mathrm{H}$. We suppose that the resident moves to the type of facility that optimally suits his/her functional capacities. The probability of transition in the model should be calculated based on the results of surveying among the older adults and the observations of moving from one type of facility to another if the supply is high enough and the facilities are affordable.

The transitions are successive according to the functional capacities of residents, the available intensity of care and available facilities. We shall denote

$: i=0$ : FH family home with fully functional and autonomous residents without the need for care;

$i=1$ : homecare in the adFH;

$i=2$ : housing unit in $\mathrm{SH}$;

$i=3$ : assisted living facility $-\mathrm{HwC}$; and

$i=4: \mathrm{NH}$;

$i=5 \operatorname{dead}(\mathrm{D})$.

The optimal structure of facilities is the structure, which accommodates residents' functional capacities so that tenure in the community $i,(i=1,2,3)$ maximise ${ }^{\mathrm{F}} T_{i}(x)$ so that the relocation to the $\mathrm{NH}$ is postponed maximally.

\subsection{Modelling flexible reverse mortgage}

In the paper, we shall develop a reverse mortgage model with embedded longevity and LTC insurance for financing LTC expenditures and optimal housing arrangement for persons with declining functional capacities.

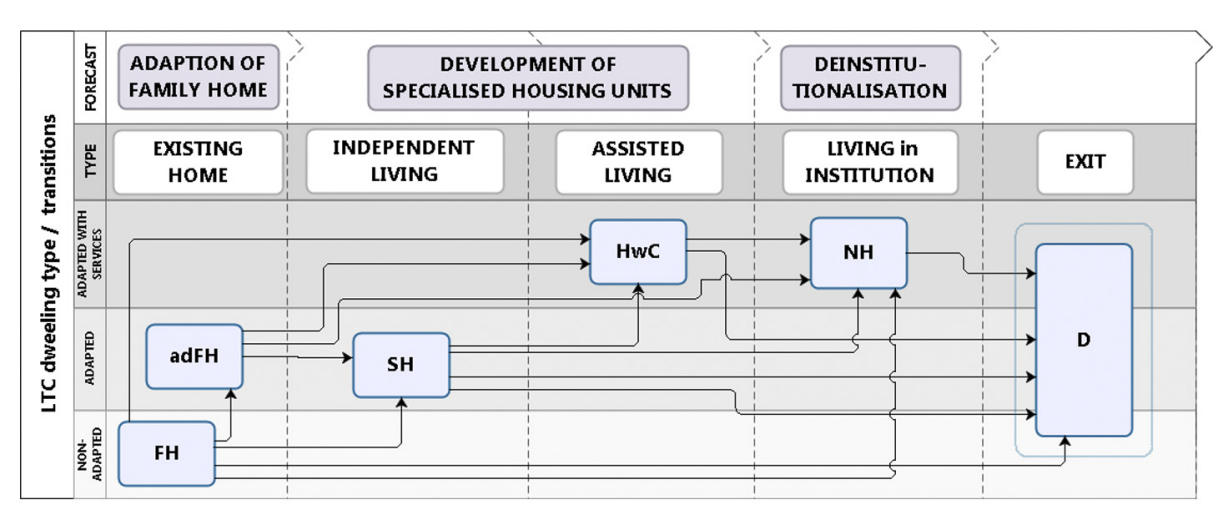

Notes: FH - family home; adFH - adapted family home; SH- sheltered housing campus;

*HwC - housing with care - assisted living facility; NH - nursing home; D -DEAD wh
Housing equity withdrawal
Figure 2.

The graph of different paths between different types of facilities from existing home to

$\mathrm{NH}$ in the multiple decrement model 
Reverse mortgage transforms the value of fixed assets in owner-occupied dwellings into liquid assets for covering LTC and housing-related costs for elderly homeowners. They, thus, enable a homeowner to access the wealth accumulated in the form of the home, while being able to continue to live in it. An illiquid asset becomes a source of liquidity, mainly for financing needs of persons that are dependent on the help of others. A reverse mortgage is a loan that will be repaid from the sale of a property, mainly after the death of the owner. Reverse mortgage is, therefore:

- financial service;

- source of liquidity for the future;

- contain a strong entitlement to remain in occupation of the property; and

- rely solely on the sale of the property for repayment/payment of the funds released to be used as a retirement pension.

The holder of a reverse mortgage contract can choose between different cash flows:

- lump-sum payment or;

- periodic (monthly, yearly) income; and

- cash on demand.

The loan is secured using a mortgage on the property. Reverse mortgage contract stipulates that repayment is made from the proceeds of the sale of the property either after the death of the homeowner or when the property has become vacated for a longer time (see details on European implementations in Reifner et al., 2009).

The actuarial notation used is described in Gerber (1980). For modelling Reverse Mortgage Contract, we use Lifetime annuity at the moment of closing of the reverse mortgage contract. The value of the property is used for repayment of the reverse mortgage loan.

Let us replace the standard notation used in actuarial mathematics as follows:

$a(x)=a_{(x)}$ The actuarial present value of the lifetime annuity for $€ 1$, paid at the beginning of each year for the person that is $x$ years old - according to the mortality table;

$p(j \mid x)={ }_{j} p_{x}$ the probability that the person that is $x$ years old will survive the next $j$ years:

$\nu=1 /(1+i)$ discounting factor where $i$ is the annual interest rate

The amount of yearly disbursement of the lifetime annuity, therefore, needs to cover the interest on the principal amount taken out and the annuity paid to the beneficiary of the reverse mortgage:

$$
a(x)=\sum_{j=0}^{110-x} p(j \mid x) \cdot v^{j}=\sum_{j=0}^{110-x} p(j \mid x) \cdot(1 /(1+i))^{j}
$$

The amount of lifetime annuity is calculated as the annuity factor multiplied by the net VRE, which is calculated as the VRE minus the cost associated with the transaction (valuation costs, taxes, costs of sale).

We shall further use the more simple expression as annuity factor $f r(x, \imath)$, which is:

$$
f r(x, i)=1 /\left\{\left(1+\gamma_{2}\right) \cdot a(x)\right\}=1 /\left\{\left(1+\gamma_{2}\right) \sum_{j=0}^{110-x} p(j \mid x) \cdot(1 /(1+i))^{j}\right\}
$$


In equation (18) the rate $\gamma_{2}$ represents the costs associated with the disbursement of the annuity, that the insurance company charges for each pay-out, in the period of the annuity.

The yearly amount of annuity $R_{h}$ is calculated according to the value of real estate VRE and annuity factor $f r(x, \imath)$ :

$$
R_{h}=f r(x, i) \cdot(V R E-C)
$$

Here $C$ are all costs associated with closing the reverse mortgage contract and with the sale of the property after the death of the beneficiary.

The maximum amount of loan (MLA) that can be drawn from the real estate is the VRE minus all the costs $(C)$, i.e. those associated with closing the reverse mortgage contract $\left(C_{1}\right)$ and with the sale of the property after the death of the beneficiary $\left(C_{2}\right)$.

$$
M L A=V R E-C=V R E-C_{1}-C_{2}
$$

A life annuity consists of a series of payments, which are made while the beneficiary (of initial age $x$ ) lives.

The present value of the life annuity due with yearly payments at the beginning of each year for $€ 1$ in next $n$ years for a person, which is $x$ years old, is denoted by $a(x \mid n)$, where the following equation can be written:

$$
a(x \mid n)=\sum_{j=0}^{n} p(j \mid x) v^{j}
$$

The present value of the life annuity deferred for $n$ years with yearly $€ 1$ payments is denoted by $b(x, n)={ }_{n \mid} a_{(x)}$, where the following equation can be written:

$$
b(x, n)=p(n \mid x) \cdot v^{n} \cdot a(x)=p(n \mid x) \cdot v^{n} \cdot \sum_{j=0}^{110-(x+n)} p(j \mid x+n) \cdot v^{j}
$$

The $\mathrm{PR}$ rate for longevity insurance $\operatorname{prs}(x, i, n)$ is:

$$
\operatorname{prs}(x, i, n)=\left(1+\gamma_{2}\right) \cdot b(x, n) /\left(1+\gamma_{1}\right) \cdot a(x \mid n)
$$

Where $\gamma_{1}$ represents the rate of administrative expenses that are charged against the policy in the period of PR payments and $\gamma_{2}$ represents the rate of administrative costs that are charged against the policy in the period of annuity payments. The yearly amount of $P R$ is calculated as:

$$
P R=\operatorname{prs}(x, i, n) \cdot R_{h}
$$

Where $R_{h}$ is the annuity amount withdrawn from the housing asset. In this case, the yearly disbursement amount that the beneficiary can draw from the real estate is:

$$
Y D A=i \cdot M L A /\left[(1+i)^{n}-1\right]=Y P A+P R=Y P A+\operatorname{prs}(x, i, n) \cdot(Y P A+M L A \cdot i)
$$

When functional capacities of homeowner decline to such level that he is no longer able to live in his own house, the homeowner's housing equity is used to purchase supported 
housing unit in the assisted-living facility or retirement community of homeowner's choice.

\subsection{Numerical example of housing equity withdrawal scheme in Slovenia}

We shall study the dynamics of the reverse mortgage income, calculated based on $1.75 \%$ interest rate on the outstanding loan and $1.75 \%$ discount rate embedded in the deferred lifetime annuity PR (male population, DAV1994R) and mortality tables for payment of PRs for male population after 65 age (male population, Slovenian mortality Tables 2007) at the following other parameters, as considered in Table 9:

- Age of residential property owner at the closing of the reverse mortgage contract is 65;

- Value of the property is constant at $€ 160,000$;

- The discount rate used by the insurance company for the calculated annuity PR is 1.75 ;

- Mortality tables used for calculating annuity PR are the same as are prescribed by the Slovenian Agency for Insurance Supervision for calculating mathematical reserves (DAV $1994 \mathrm{R}$ );

- Administrative costs for payment processing and disbursement are estimated at $5 \%$ of the PR and annuity amount accordingly;

- The interest rate on an outstanding loan charged by the financial institution is $1.75 \%$;

- Closing costs are counted at $2 \%$ of the value of the property;

- Accounting costs are fixed at $€ 120$ per amount;

- Longevity PR amounts €2,948.98;

- LTC PR is calculated as NPV of LTC costs for social care based on the healthcare tables (ZZZS, 2017): €8 per $0.5 \mathrm{~h}$, €16 per $1 \mathrm{~h}$, €24 per $1.5 \mathrm{~h}$ per day, the yearly PR payable for 16 years: $€ 420.64$; and

- Monthly disbursement for $€ 333.33$.

In the case of the residential property value, which equals $€ 160,000$, which is not growing through the time horizon of owners lifespan all the costs associated with the closing of a reverse mortgage contract (brokerage fee, assessment fee, notary fee and other administration costs) are $2 \%(€ 3,200)$. The yearly amount drawn from the residential real estate equity is equal to $€ 7,517.18$. This amount is then divided into three parts $€ 120.00$ covers administration fee, for maintaining reverse mortgage account with a financial institution, the amount of $€ 2,948.98$ is used for purchasing the annuity PR that covers the annuities after exhausting all the equity in the residential real estate property (in case that real-estate owner is living longer than expected). The yearly amount of $€ 4,000$ is disbursed to the property owner, who is staying in his property until the end of his life in any case. At the end of his life, the costs of refurbishing and selling the property are covered by remaining $€ 7,156.46$. After renovating the house is sold for $€ 160,000$, which was also estimated price at the beginning of the time horizon of our simulation.

\subsection{The transition from own home to a privately owned assisted-living housing unit}

Let's assume the case that after living in his owned house of 11 years function capacity of homeowner declines so that he is no longer able to live in his own home under the stipulation 
of flexible reverse mortgage contract he is allowed to sell his hose unit and buy assistedliving housing unit for $€ 120,000$. The proceeds of sale above the purchase price for $€ 40.000$ are used for repayment of the loan and the new reverse mortgage scheme is the following, as given in Table 10:

\subsection{Mitigating the risk of dependence on the help of others}

To prevent adverse selection and moral hazard assessment of LTC risk should be part of the underwriting process. Right to coverage of the social part of home-care and community care services under the LTC insurance contract should be subject to the individual's risk assessment. Eligibility and risk PR should be based on the professional assessment of functional capacities of the beneficiary, physical characteristics of the housing unit and social care needs of insured. The proper prescription process should be defined. Without adequate insurance for LTC risks, real estate cannot be used as the vehicle for financing LTC expenditures in community care, because the equity release without LTC insurance presents a considerable risk for the insured older adult that he will not have sufficient funds to cover LTC expenditures when he becomes dependent on the help of others. The standard annuity does not cover increasing expenses for care due to declining functional capacities of the beneficiary.

Housing equity scheme, including LTC insurance, can be underwritten even when the need for care has already materialised. However, then the risks and associated probabilities are different. Reverse mortgage contract, which is underwritten, when the homeowner is already dependent on the help of others, has different probabilities ${ }^{\tau+j} p_{x+j}^{L T C 1},{ }^{\tau+j} p_{x+j}^{L T C 2},{ }^{\tau+j} p_{x+j}^{L T C 3}$ that insured will be dependent on the help of others and in a particular category of care. The actuarial present value of LTC services provided should be calculated under the assumption of the equivalence of the actuarial present values.

\subsection{Mitigating the risk of longevity}

The main risks concerning the reverse mortgage that can cause credit default are:

- the uncertain longevity of the owner-occupier, realised when the value of a property being sold does not cover the amount of loan;

- the risk of an increase in interest rates;

- and depreciation in the value of the property, subject of some political reasons (Černe et al., 2012).

Deferred annuity as insurance for longevity is already used in the insurance industry, but not in combination with a reverse mortgage as the one proposed here. Sustainability and market consistency regarding longevity are among the main concerns of The Actuarial Association of Europe ${ }^{1}$.

Without adequate insurance for longevity and LTC risks, real estate cannot be used as the vehicle for financing LTC expenditures in community care, because the equity release without longevity insurance presents a considerable risk for the provider of a reverse mortgage (bank) and is not covering increasing expenditures for the care of the beneficiary. For the reverse mortgage provider, there is the risk that the value of the loan together with accrued interest will be higher than the VRE in case of the death of the beneficiary. For the beneficiary, there is the risk that he will live longer than the agreed period of drawing liquid amounts that are defined in the reverse mortgage loan contract. A safe reverse mortgage contract also needs to include a kind of insurance for longevity. This insurance can be provided in three ways: 


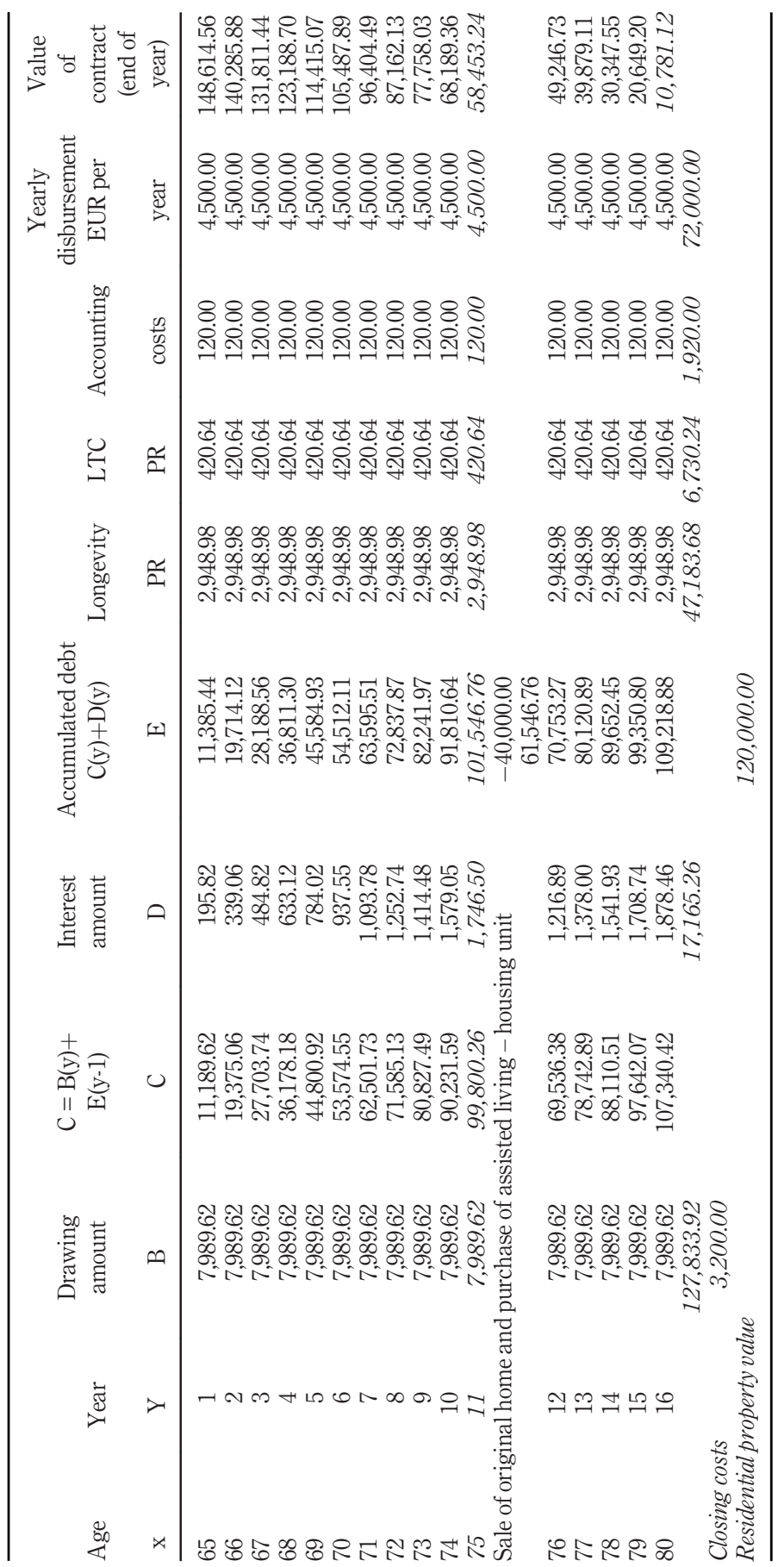


- Through public finance so that the risk is socialised and the management of risk is assumed by the government (as is the case in the USA where The Home Equity Conversion Mortgages Insurance is a clear example of such a scheme. Lenders under this programme are protected against losses arising when the loan balance exceeds the VRE at the time of settlement. However, because of implicit government guarantees underlying this insurance, it may become a severe drain on the fiscus, as the market expands after the crisis, as also described by Wang et al. (2008) and Chen et al. (2010);

- The risk can be transferred to insurance companies. According to the results in Blake et al. (2013), the enormous economic significance of the longevity risk has begun to be recognised and quantified in their article, presenting the birth and development of the Life Market, the new market related to the transfer of longevity and mortality risks. The authors note that the emergence of a traded market in longevity-linked capital market instruments could act as a catalyst to help facilitate the development of annuity markets, both in the developed and the developing worlds and protect the long-term viability of retirement income provision globally. The possible instruments have been studied and developed also in Lee et al. (2012) and Yang and Wang (2013);

- The third way is possible through a mutual insurance company, as proposed in Bogataj (2013a, 2013b) and inherently present in this paper. The risk of longevity can be mitigated by the use of annuity insurance where legal, obligatory mortality tables in Slovenia are German DAV1994R, which is close to mortality projection 2050; hence, insurance companies benefit on an overestimation of longevity today. Indeed, it is better to share the benefit of this overestimation among the remaining seniors, but it is difficult to avoid the impact of the volatile interest rate (Figure 3).

As followed from Figure 1, in the past 67 years, the long-term interest rate was very volatile and it was in the range between 2 and 16. Long-term interest rate influences the affordability of reverse mortgage for homeowners.

We can calculate PRs for LTC insurance at a different interest rate, as presented in Table 11.

From Figure 4, we can see that real estate values fluctuate over time, so in the event of a collapse in the value of real estate market, there is a risk that the bank, as a lender, will not be able to settle the reverse mortgage loan by selling a property.

But nominal values were growing for most of the time (Figure 5)

Table 12, Showing the relative frequency of indexes of nominal real estate price growth over 22 years - moving 22 -year intervals, explain that in the USA, in the time horizon 1890-

Figure 3.

US long-term interest rate in $\%$ in period 1950-2017

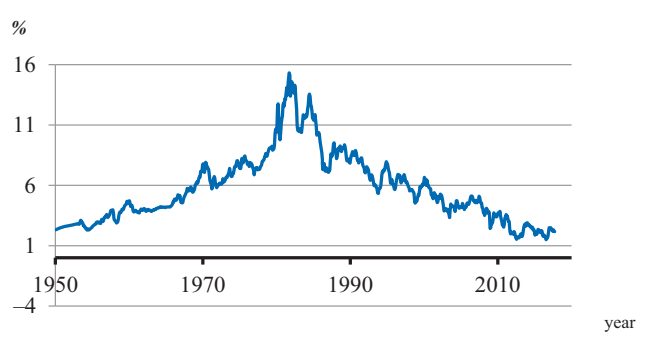

Source: Shiller, 2005 +updates 


\begin{tabular}{|c|c|c|c|c|}
\hline $\begin{array}{l}\text { Interest } \\
\text { rate }\end{array}$ & APV & $P_{65}^{L T C}$ & $\begin{array}{c}\text { Male } \\
P_{25: 40}^{L T C} \\
\end{array}$ & $P_{65: 16}^{L T C}$ \\
\hline 1.00 & $6,060.27$ & $6,363.28$ & 71.34 & 450.60 \\
\hline 1.75 & $5,363.46$ & $5,631.63$ & 46.97 & 420.64 \\
\hline 2.00 & $5,154.75$ & $5,412.49$ & 40.92 & 411.38 \\
\hline 3.00 & $4,420.24$ & $4,641.25$ & 23.75 & 377.61 \\
\hline 4.00 & $3,820.56$ & $4,011.59$ & 13.95 & 348.46 \\
\hline 5.00 & $3,327.78$ & $3,494.17$ & 8.29 & 323.21 \\
\hline 6.00 & $2,920.28$ & $3,066.29$ & 4.98 & 301.31 \\
\hline 7.00 & $2,581.17$ & $2,710.23$ & 3.02 & 282.24 \\
\hline 8.00 & $2,297.24$ & $2,412.10$ & 1.85 & 265.61 \\
\hline 9.00 & $2,058.07$ & $2,160.97$ & 1.15 & 251.05 \\
\hline 10.00 & $1,855.42$ & $1,948.19$ & 0.72 & 238.29 \\
\hline
\end{tabular}

APV - Actuarial present value

Housing equity withdrawal

\section{Table 11.}

The influence of the interest rate on PRs

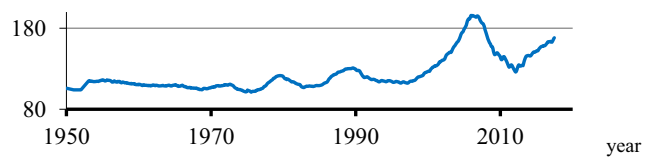

Source: Robert J. Shiller, Irrational Exuberance, 3rd. Edition, Princeton University Press, 2015, as updated by the authors

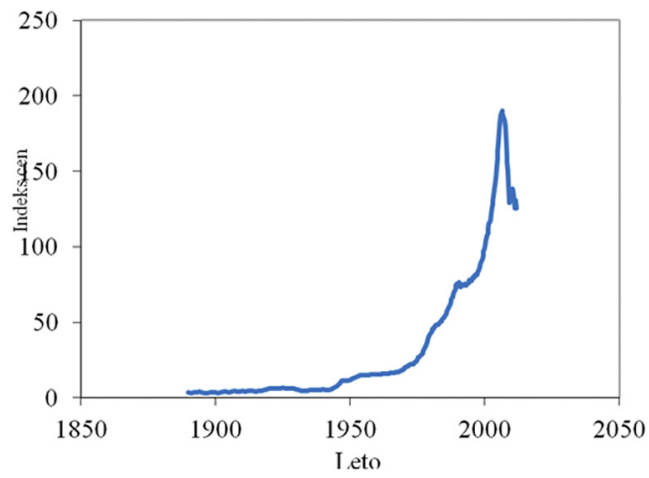

Source: Robert J. Shiller, Irrational Exuberance, 3rd. Edition, Princeton University Press, 2015, as updated by the authors
Figure 4.

Volatility of Home Prices (in \%: 18902017) in the USA
Figure 5.

Nominal Home Prices (1890-2017) in the USA

2012 only in $3 \%$ of 22 years moving ranges the price after 22 years was lower than at the beginning of the interval. The highest drop in the nominal values was equal to $16 \%$. This risk we can mitigate by futures and future options on Case-Shiller index, traded on the Chicago mercantile exchange 


\section{Discussion}

As stated in the Operational Programme 2014-2020, Slovenia does not have a comprehensive system for the regulation of LTC. Services and demand are arising from the different existing systems:

- health;

- pension and disability insurance and from the; and

- social welfare system.

Given the demographic structure and projections, developed by EC and presented in The Ageing Report 2018, the number of persons dependent on the help of others will more than double in the next 20 years, also in Slovenia. The reform of LTC system will enable the establishment of a uniform system of high-quality community-based services for ageing in the community including home care, supported housing in assisted-living facilities and NHs for those that will need institutional forms of care. Slovenia is preparing new legislation in the field of LTC, which will have to take into consideration also different types of facilities where LTC services will be provided. These further attempts will require the development of a model for projections of needs and capacities for integrated health and social services, LTC, monitoring of recipients of services and funds for LTC and coordinating the development of integrated community-based services, as required in Operational Programme 2014-2020. How to finance these programmes is not clear yet.

In 2016, the average old-age pension in Slovenia was $€ 620$ per month. One hour of homecare par day was $€ 16$ and $480 \mathrm{EU}$ per month. Therefore, expenditures for one hour of homecare per day consumed $77,4 \%$ of the average pension, two hours of home-care per day consumed $154,8 \%$ of the average pension income and three hours of home care per day consumed $232,2 \%$ of the average pension income. Even though currently, municipalities are already financing $50 \%$ of expenditures for home care, it is not affordable for the most older adult. In the case of Slovenia reverse mortgage could be used to finance out of pocket expenses. In the case of asset-based financing of LTC expenditures, the income taxes or the social contributions would be lower and LTC provision in the community more affordable. In Slovenia, currently, the municipality would pay for the $\mathrm{NH}$ for residents without enough income to cover the expenditures and repay itself from sale the properties of the user of this service. However, the municipality would cover only $50 \%$ of home care expenditures. In the case that reverse mortgage with LTC insurance would be available in Slovenia, this person could stay in the community and would not need to relocate to a NH.

Delfani et al. (2014) qualify the role of homeownership as an income complement in any EU country. They argue that a strategy of asset-based welfare focussed on the promotion of homeownership is not universally applicable but depends on how housing and pension provision are organised. This complementarity, however, often also depends heavily on the

Table 12.

Relative frequency of indexes of nominal real estate price growth over 22 years - moving 22-year intervals in USA in the time horizon 1890-2012

\begin{tabular}{lc}
\hline Bin & Frequency \\
\hline$(84,100)$ & 3 \\
$(100,200)$ & 47 \\
$(200,300)$ & 22 \\
$(300,400)$ & 25 \\
$(400,440)]$ & 3
\end{tabular}

Source: Shiller (2015), as calculated by the authors 
available banking or insurance products. In the paper, we shall develop a model forecasting the demand for LTC services and facilities, for which even the documents od European Commission state that has not yet been developed and show how the optimal policy requires higher dynamics of providing facilities for older adults. We shall present a more scientific measuring instrument, based on the actuarial-mathematical methods. LTC insurance model will be developed and embedded in a reverse mortgage financial instrument. According to principle 18 of the European Pillar of Social Rights on LTC, Europeans have the right to affordable LTC services of good quality, in particular home-care and community-based services. How to finance these services is at the core of political debates in EU member states. Eligibility for publicly funded long.term care services (including through health insurance schemes, LTC insurance schemes and state budgets) can be subject to the care needs, income and assets of the dependent older adult and the availability of family carers. The residents usually bear accommodation costs (meals, housing) in residential settings. In nearly all EU member states, out-of-pocket payments of LTC users and their relatives are required both for home care services and for residential care. Quality of housing stock is a significant issue when considering the development of home care and community-based LTC services. The housing stock in Europe is not fit to support a shift from institutional care to the home-based independent living. According to the report of European Innovation Partnership on Active and Healthy Ageing, some $90 \%$ of houses in the UK and $70 \%-80 \%$ in Germany are not adequately built for the older adults with declining functional capacities. Our recent results in Slovenia show that only $40 \%$ of the older adults think that their family home is suitable enough for ageing in place, while the other $60 \%$ is expecting that they will need to move to the assisted living facilities or NHs after substantial decline of their functional capacities (Bogataj et al., 2019). The studies of Wood (2017) and current evidence of Housing LIN listed at www.housinglin.org.uk/Topics/type/ has shown that the vast majority of residents in sheltered housing "feel more sociable, more autonomous, safer, healthier and overall happier" in comparison with other options. Therefore, the technical properties of housing units should be adopted to the abilities of older adults. To move in such adapted homes, the residents can lease or own the property.

Sheltered housing is developed in the English-speaking world, but in Eastern and Southern Europe are underdeveloped. In terms of financial capabilities, renting is easier for western Europeans, while eastern Europeans have low monthly earnings, but are asset rich by owning real estate in which they reside. Table 2 shows that the inhabitants of most Eastern European and Southern European countries own a large proportion of the houses and apartments in which they live. These are often too big for the single-family households of the old adults and are not adequately built for the person with declined functional capacities. The option of these cohorts would be to choose an equity release schemes (ERS) product. Current reverse mortgage products like home equity conversion mortgages in the USA and the reverse mortgage schemes offered by financial institutions in the UK stipulate that the contract ends after the homeowner moves out of the property when the financial institutions get the right to sell the property under the reverse mortgage and repay the loan. Such products make it difficult to purchase a well-adapted home in assisted living facilities, extra care housing, $\mathrm{HwC}$ or an assisted living facility in a retirement community. The only option for an older adult is to move directly to a $\mathrm{NH}$, resulting in enormous public and/or private expenditures.

We have shown that by using actuarial mathematics, the current reverse mortgage contracts can be improved so that the equity in the property can be preserved even when the family home is sold and a unit in the assisted living facility is purchased under the parameters determined in advance. The product remains risky for contractors because of the 
volatile real estate market and unknown longevity of homeowners. According to the CaseShiller index in the past 130 years in $6 \%$ of cases, this index was below 100 after 16 years (Bogataj, 2013a, 2013b). These risks are insurable. Product is also exposed to the interest rate risk, which can be mitigated with standardised and tailored financial derivatives.

Therefore, the scheme has been adjusted, so that also enables multiple moving from a single-family house to owner-occupied flats in the assistant living facilities adapted to the functional capacities of the residents. All these changes of housing property are possible under a single contract scheme and could also finance the $\mathrm{NH}$ when needed with the lifetime annuity from built up the insurance reserves. According to EUROBAROMETER 283, 25\% of older adults consider using housing equity as an acceptable option. However, in most Eastern European countries, there is no specific legislation to regulate a reverse mortgage so that the user's property rights would be protected.

In the USA, Loan-to-Value is between $50 \%$ and $65 \%$ from where the interest is covered from the lifetime annuities, as MLA includes the capitalised interest rate. In our model, the expenditures and charges are very transparently presented and not just hidden in a loan-tovalue ratio and the payment of interest is insured for the lifetime of the borrower. The MLA to VRE is not the same as the loan-to-value. Therefore, our product is less exposed to risk for financial institutions. The expenditures $\mathrm{Cl}$ in our model associated with reverse mortgages and fees can include advisor/broker fees, legal expenses, property valuation, arrangement fees and completion fees. Expenditures related to the sale of the property C2 include preparation of a property for sale, legal fees, closing of the contract, real estate broker commission and other expenses related to the sale of the property. In our model, MLA incorporates capitalised interest and not only the cash flow disbursed to the property owner. Our model consists of all transaction costs connected with the property, except:

- the interest rate,

- the longevity PR; and

- the LTC insurance PRs in C, which are embedded in the actuarial calculations.

Therefore, the parameters in the model are more transparent than in the current reverse mortgage products for a user. $\mathrm{C}$ depends on the system of real estate management and the sales process established. From our research in Slovenia, reverse mortgage products are acceptable for homeowners only if the interest rate is low enough. Transparent presentation of expenditures and charges are essential for the clients. The efficient and affordable riskmanagement mechanism is needed as suggested in the scheme. For the government, it is much cheaper to subsidise the interest rate and to accept the real estate value risk than to finance $100 \%$ of LTC from the budget.

\section{Conclusions and the plan for further research discussion}

We have present how ERS could transform a value tied in fixed assets of owner-occupied homes into cash flows for covering LTC expenditures and housing in Assisted-Living Facilities, which is adjusted to the old inhabitants. The model allows preparing an insurance scheme for each inhabitant for moving to an appropriate home by multiple relocations to a housing unit in assisted-living facilities when functional impairments of homeowner do not let him/her overcome barriers of build environment in hihe/sher current home. LTC insurance financed with the homeowner's housing equity is a relatively cheap way to provide coverage for expenditure for LTC needs in old age. Namely, the cost of LTC can be as high as the value of one's home. Reverse mortgage transforms fixed assets in owner-occupied dwellings into liquid assets for financing 
expenditure for age-friendly housing and LTC needs in the old age. We have shown that the properly structured reverse mortgage scheme with embedded LTC insurance can assure the homeowner that he/she will age-independent and autonomous with the amount of care that fits his functional capacity.

We have also shown how the variation of an interest rate changes the income based on housing equity withdrawal. The numerical example is based on the data of the average value of a home owned by seniors in Slovenian regions and the expenditures for LTC provision taking in the account the costs of care in different categories of care. The numerical example is based on the Mortality Tables DAV1994R, as required by law. The probabilities that someone becomes dependent on the help of others was derived from National Health Insurance data for $\mathrm{NH}$ residents adding the list of those who are waiting for endorsement. The paper exposes the need for a comprehensive information system on LTC services that would include the data on users of LTC and applications for LTC endorsements including home care, assisted-living facilities and the NH. Such information would provide better knowledge for insurance companies and banks regarding cash flows associated with financing LTC expenditure and assisted-living facilities. Such an information system would allow them to develop better insurance and reverse mortgage financial products. This information would allow municipalities, developers and investors in assisted-living facilities to improve the spatial planning and planning of investments in assisted-living facilities on the municipality level.

This model is an innovation - a new insurance product; therefore, we have no statistics about how many potential policyholders we can expect. In Slovenia and many other new EU member states, health care is publicly funded, but the social part of home care is not. Many owners of a housing unit have too low pension to pay the social services and a safe, accessible HwC. With the insurance product developed here, the banks and insurance companies can open the lines even later when needed, when the homeowner become dependent on the help of others. In any case, the services required they could provide under the assumption of the equivalence of the actuarial present values. Therefore, also the statistics for improving such product should be part of further research.

The differences between life expectancies in the retirement village and the general environment have been calculated for women in the UK and the value was equal to 4.5 years. The probability of falls in the sheltered housing is half of the probability in a general family home environment. Relationship between the built environment, life expectancy and demand for LTC services should be subject to further research and modelling. Further study should include the assessment of investments in the proper assisted-living facilities and community care for persons that are dependent on the help of others, associated with the analysis of the cost of health-care and longevity of residents. Further research is proposed regarding how the introduction of LTC insurance would influence the frequency and severity of LTC claims. There is a reason to expect that more accommodative age-friendly environment and community care would increase the life expectancy of older adults and decrease the expenditure for LTC and LTC PRs (Wood, 2017; Berrington, 2017). So, further studies of the probability of transitions and the risks mitigated by LTC insurance and longevity insurance embedded in a reverse mortgage is proposed. Further research regarding the social value of assisted-living facilities and its influence on urban land rent is recommended, especially in connection with the impact of sheltered housing and assisted-living facilities on health and healthrelated expenditures of residents. 


\section{References}

Arntz, M., Sacchetto, R., Spermann, A., Steffes, S. and Widmaier, S. (2007), "The german social longterm care insurance: structure and reform options", Discussion Paper No. 2625, Institute for the Study of Labor, Bonn.

Berrington, J. (2017), The Value of Sheltered Housing, National Housing Federation, London.

Black, K. and Dobbs, D. (2013), "Community-dwelling older adults' perceptions of dignity: core meanings, supports, challenges, and opportunities", Ageing and Society Advance Online Publication, doi: 10.1017/S0144686X13000020.

Black, K. and Dobbs, D. (2015), “Community-Dwelling older adults' perspectives on what matters most: findings from an exploratory inquiry", Activities, Adaptation and Aging, Vol. 39 No. 2, pp. 133-152, doi: 10.1080/01924788.2015.1025674.

Blake, D., Cairns, A.J.G., Coughlan, G., Dowd, K. and MacMinn, R. (2013), “The new life market”, Journal of Risk and Insurance, Vol. 80 No. 3, pp. 501-558.

Bocquaire, E. (2016), Long-Term Care Coverage in Europe, S. 1.: L'Argus de l'assurance.

Bogataj, D., et al. (2013a), "Pensions and homeownership in the welfare mix for an older person", in Zadnik Stirn, L. and Vodopivec, R., (Ed.), SOR '13 Proceedings, pp. 281-286, Slovenian Society Informatika, Section for Operational Research, Ljubljana.

Bogataj, D. (2013b), Vlagaj v Svoj Dom, da Boš Dolgo Živel in ti bo Dobro na Zemlji (=Invest in Your Home to Live Long and You Will Be Well on Earth), MEDIFAS, MEORL, No. 13. Nova Gorica.

Bogataj, D. and Bogataj, M. (2015), "Housing equity withdrawal in the portfolio choice for deferred pension income", International Journal of Social Sciences and Humanities Invention, Vol. 2 No. 7 , pp. 1459-1473.

Bogataj, D., Ros McDonnell, D. and Bogataj, M. (2015a), "Reverse mortgage schemes financing urban dynamics using the multiple decrement approach", Springer Proceedings in Mathematics and Statistics 135, Springer.

Bogataj, D., Ros McDonnell, D. and Bogataj, M. (2015b), "Financing urban growth in aging societies: Modelling the equity release schemes in the welfare mix for older persons", $V$ : Enhancing Synergies in a Collaborative Environment, Springer, Cham.

Bogataj, D., Szander, D. and Ros McDonnell, D. (2015), "Španski model bivalnega prostora in zagotavljanje dolgotrajne oskrbe”, in Ros McDonnell, L., Bogataj, D. and Kavšek, M. (Eds), Dolgotrajna Oskrba: izzivi in Priložnosti: oskrbovalni in Bivalni Vidiki, (MEORL, Serijska št. 19), MEDIFAS; Ljubljana, Šempeter pri Gorici, Skupnost socialnih zavodov Slovenije.

Bogataj, D., Ros-McDonnell, D. and Bogataj, M. (2016), "Management, financing and taxation of housing stock in the shrinking cities of aging societies", International Journal of Production Economics, Vol. 181, pp. 2-13.

Bogataj, D., Kavšek, M., Bogataj, M. and Rogelj, V. (2019), Analiza Obstoječih Možnosti za Vzpostavitev Koncepta Pametnih Vasi: porocilo (= an Analysis of Existing Possibilities for Establishing the Smart Village Concept: A Research Report), Zavod INRISK, Trebnje.

Boletin Oficial del Estad (2006), BOE-A-2006-21990. (39/2006). Ministerio de sanidad, servicios sociales e igualdad. Ley 39/2006, de 14 de diciembre, de Promoción de la Autonomía Personal y Atención a las personas en situación de dependencia.

Boletin Oficial del Estado (2011), BOE-A-2011-3174. (174/2011). Real Decreto Legislativo 1/2013, de 29 de noviembre, por el que se aprueba el Texto Refundido de la Ley General de derechos de las personas con discapacidad y de su inclusión social.

Boletin Oficial del Estado (2013a), BOE-A-2013-13810. (1050/2013). Real Decreto 1050/2013, de 27 de diciembre, por el que se regula el nivel mínimo de protección establecido en la Ley 39/2006, de 14 de diciembre, de Promoción de la Autonomía Personal y Atención a las personas en situación de dependencia. 
Boletin Oficial del Estado (2013b), BOE-A-2013-13231. (SSI/2371/2013). Orden SSI/2371/2013, de 17 de diciembre, por la que se regula el Sistema de Información del Sistema para la Autonomía y Atención a la Dependencia.

Canadian Centre on Disabilities Studies (2014), "VisitAbility project", available at: http:// VisitAbleHousingCanada.com

Černe, J., Temeljotov Salaj, A. and Števančec, D. (2012), "Dejavniki sprememb slovenskega trga nepremičnin po vstopu v evropske integracije”, Teor. praksa, Vol. 49 No. 1, pp. 229-230.

Chapin, R.K. and Dobbs-Kepper, D. (2001), “Aging in place in assisted living: philosophy versus policy”, The Gerontologist, Vol. 41 No. 1, pp. 43-50.

Chen, H., Cox, S.H. and Wang, S.S. (2010), "Is the home equity conversion mortgage in the United States sustainable? Evidence from pricing mortgage insurance premiums and non-recourse provisions using the conditional esscher transform”, Insurance: Mathematics and Economics, Vol. 46 No. 2, pp. 371-384.

Comas-Herrera, A., Pickard, L., Wittenberg, R., Malley, J. and King, D. (2010), "The long-term care system for the elderly in England", Enepri research report no. 74. ANCIEN.

Costa-Font, J. (2013), "Housing-related well-being in older people: the impact of environmental and financial influences", Urban Studies, Vol. 50 No. 4, pp. 657-673.

Council of Europe (1950), "Convention for the protection of human rights and fundamental freedoms (European convention on human rights, as amended) (ECHR) art 3.Rome".

Council of Europe (2013), "OJ C 217, paragraph 2", available at: https://eur-lex.europa.eu/legal-c5

Czibere, K. and Gal, R.I. (2010), "The Long-Term care system for the elderly in Hungary”, Enepri research report no. 79. ANCIEN.

Daaleman, T.P., Williams, C.S., Hamilton, V.L. and Zimmerman, S. (2008), "Spiritual care at the end of life in long -term care", Medical Care, Vol. 46 No. 1, pp. 85-91.

Davis, B. (2009), "Older people's assets: using housing equity to pay for health and aged care", JASSA, Vol. 4 No. 2009, pp. $43-47$.

De Decker, P. and Dewilde, C. (2010), "Homeownership and asset-based welfare: the case of Belgium", Journal of Housing and the Built Environment, Vol. 25 No. 2, pp. 243-262.

Delfani, N., De Deken, J. and Dewilde, C. (2014), "Home-Ownership and pensions: negative correlation, but no trade-off”, Housing Studies, Vol. 29 No. 5, pp. 657-676.

Department of Planning and Community Development (2010), "Visitable and adaptable features in housing, regulatory impact statement", Victorian Government, available at: www.google.es/ search? site $=\&$ source $=h p \& q=$ visitable + and + adaptable + features + in + housing\&oq=visitable + housing\&gs_l=hp.1.4.35i39k1j0j0i30k1j0i5i30k1j0i8i30k1.2518.14835.0.24069.20.20.0.0.0.0.824. 3374.0j10j2j2j6-1.15.0...0.0..1c.1.64.hp.5.10.1881.0.0i13k1j0i13i10k1j0i13i30k1.wYpMluqI86Y ontent/EN/TXT/?uri=CELEX $\% 3 \mathrm{~A} 32013 \mathrm{H} 0730 \% 2815 \% 29$

Doling, J. and Ronald, R. (2010a), "Home ownership and asset-based welfare", Journal of Housing and the Built Environment, Vol. 25 No. 2, pp. 165-173.

Doling, J. and Ronald, R. (2010b), "Property-based welfare and European homeowners: how would housing perform as a pension?", Journal of Housing and the Built Environment, Vol. 25 No. 2, pp. $227-241$.

Doling, J. and Ronald, R. (2012), "Meeting the income needs of older people in East Asia: using housing", Ageing and Society, Vol. 32 No. 3, pp. 471-490.

Drobež, E. and Bogataj, D. (2016), "Housing rights of seniors in the process of deinstitutionalization = pravica starostnikov do stanovanja v procesu deinstitucionalizacije", V: Grum, B. (ur.), Temeljotov Salaj, A. (ur.), Proceedings, 1st Conference of Interdisciplinary Research on Real Estate, Institute of Real Estate Studies, Ljubljana, pp. 273-228. 
Drobne, S. and Bogataj, M. (2014), "Regions for servicing old people: case study of Slovenia”, Business Systems Research Journal, Vol. 5 No. 3, pp. 19-36. ISSN 1847-8344.

Drobne, S. and Bogataj, M. (2015), "Optimal allocation of public service centres in the central places of functional regions”, IFAC-PapersOnLine, Vol. 48 No. 3, pp. 2362-2367.

EC (2007), Eurobarometer 283: Health and long term care in the European Union, European Commision (EC), Brussels.

EC (2018a), The 2018 Ageing Report - Economic \& Budgetary Projections for the 28 EU Member States, 2016-2070, European Commission (EC), Luxembourg, available at: https://ec.europa.eu/info/ publications/economy-finance/2018-ageing-report-economic-and-budgetary-projections-eumember-states-2016-2070_en (accessed 23 April 2019).

European Commission (2010), "GREEN PAPER-Towards adequate, sustainable and safe european pension systems", COM(2010)365 final, Brussels.

European Commission (2015a), The 2015 Ageing Report. Underlying Assumptions and Projection Methodologies, Found 18. April 2018, available at: www.ec.europe.eu/ecomoy_finance/ publications/european_economy/ageing_report/index_en.htm

European Commission (2015b), European Summit on Innovation for Active and Healthy Ageing, 9-10 March 2015 Final Report, European Union, Brussels.

European innovation partnership on Active and Healthy Ageing (EIP on AHA) (2015), Innovation for Active and Healthy Ageing, European Summit on Innovation for Active and Healthy Ageing, 910 March 2015 Final Report, European Commission, Brussels.

Eurostat (2018), "Population structure and ageing", available at: https://ec.europa.eu/eurostat/statisticsexplained/index.php/Population_structure_and_ageing (accessed 22 January 2019).

Fiel, E.M., Walker, M.H. and Orrell, M.W. (2002), "Social networks and health of older people living in sheltered housing”, Aging and Mental Health, Vol. 6 No. 4, pp. 372-386.

Gerber, H.U. (1980), Life Insurance Mathematics, Swiss Association of Actuaries, Springer, Berlin, Heidelberg, New York, NY.

Gordon, A.L., Blundell, A.G., Gladman, J.R.F. and Masud, T. (2010), “Are we teaching our students what they need to know about ageing? Results from the UK National Survey of Undergraduate Teaching in Ageing and Geriatric Medicine", Age and Ageing, Vol. 39 No. 3, pp. 385-388.

Gutiérrez, L.F., Martin, S.J., Sanchez, R.V. and Vilaplana, C. (2010), The long-term care system for the elderly in Spain, Enepri research report No. 88, European Network of Economic Policy Research Institutes (ENEPRI), Brussels.

Haffner, M.E.A., Ong, R. and Wood, G.A. (2015), "Mortgage equity withdrawal and institutional settings: an exploratory analysis of six countries", International Journal of Housing Policy, Vol. 15 No. 3, pp. 235-259.

Janež, P., Bogataj, M. and Drobne, S. (2016), "Impact of the real estate taxation and municipal revenue on dynamics of internal migration: case study for city municipal of Ljubljana Geodetski vestnik", Geodetski Vestnik, Vol. 60 No. 4, pp. 644-684.

Kalache, A. and Plouffe, L. (2007), Global Age Friendly Cities Guide, WHO Press, Geneva, Found 1. September 2017, available at: www.who.int/ageing/publications

Kavšek, M. and Bogataj, D. (2017a), "Towards new quality standards of long-term care in Slovenia”, Revija Za Univerzalno Odličnost, Vol. 6 No. 1, pp. 11-24.

Lee, Y.T., Wang, C.W. and Huang, H.-C. (2012), "On the valuation of reverse mortgages with regular tenure payments”, Insurance: Mathematics and Economics, Vol. 51 No. 2, pp. 430-441.

Malpass, P. (2008), "Housing and the new welfare state: Wobbly pillar or cornerstone?", Housing Studies, Vol. 23 No. 1, pp. 1-19. 
Mandič, S. (2010), "The changing role of housing assets in post-socialist countries”, Journal of Housing and the Built Environment, Vol. 25 No. 2, pp. 213-226.

Manzo, L.K.C., Druta, O. and Ronald, R. (2019), "Supported home ownership and adult independence in milan: the gilded cage of family housing gifts and transfers", Sociology, Vol. 53 No. 3, pp. 519-537.

Margolis, H. (2015), Elder Law Portfolio, Wolter Kluwers, New York, NY.

Nagode, M., Kovač, N. and Lebar, L. (2015a), Analiza Organiziranosti in Izvajanja Oskrbe Na Področju Oskrbovanih Stanovanj, Končno Poročilo Naloge ANALIZA Izvajanja Pomoči Na Domu in Oskrbe V Oskrbovanih Stanovanjih, Inštitut RS za socialno varstvo (IRSSV), Ljubljana.

Nagode, M., Kovač, N. and Lebar, L. (2015b), Seznam Oskrbovanih Stanovanj, Inštitut RS za socialno varstvo (IRSSV), Ljubljana.

Nagode, M., Zver, E., Marn, S., Jacović, A. and Dominkuš, D. (2014), Dolgotrajna Oskrba - Uporaba Mednarodne Definicije v Sloveniji, Delovni zvezek, 2/2014 (XXIII), Urad RS za makroekonomske analize in razvoj, Ljubljana.

Nasar, J. and Elmer, J.R. (2016), "Homeowner and homebuyer impressions of visitable features", Disability and Health Journal, Vol. 9 No. 1.

Park, N.S., Dobbs, D., Carrion, I.V., Young, T.L, Salmon, J.R. and Roff, L.L. (2013), Parliamentary Office for Science and Technology, Housing and health.

Ong, R. (2008), "Unlocking housing equity through reverse mortgages: the case of elderly homeowners in Australia", European Journal of Housing Policy, Vol. 8 No. 1, pp. 61-79.

Rasmussen, D.W., Megbolugbe, I.F. and Morgan, B.A. (1997), "The reverse mortgage as an asset management tool", Housing Policy Debate, Vol. 8 No. 1, pp. 173-194.

Reifner, U., Clerc-Renaud, S., Pérez-Carrillo, E.F., Tiffe, A. and Knobloch, M. (2009), Study on Equity Release Schemes in the EU, Institut für Finanzdienstleistungen e.V., Hamburg.

Riedel, M. and Kraus, M. (2010), "The Long-Term care system for the elderly in Austria”, Enepri research report no. 69. ANCIEN.

Rohe, W., Van Zandt, S. and McCarthy, G. (2001), "The social benefits and cost of home ownership: a critical assessment of research", Working Paper No. LIHO-01.12, Joint Center for Housing Studies, Harvard University, Harvard.

Rogers, D., Dufty-Jones, R. and Steele, W. (2015), "Housing and socio-spatial inclusion”, Social Inclusion, Vol. 3 No. 2, pp. 1-5.

Ronald, R. and Doling, J. (2012), "Testing home ownership as the cornerstone of welfare: lessons from East Asia for the West", Housing Studies, Vol. 27 No. 7, pp. 940-961.

Rossi, P.H. and Weber, E. (1996), "The social benefits of homeownership: empirical evidence from National Surveys", Housing Policy Debate, Vol. 7, pp. 1-35.

Rothschild, M. and Stiglitz, J. (1976), "Equilibrium in competitive insurance markets: an essay on the economics of imperfect information", The Quarterly Journal of Economics, Vol. 90 No. 4, pp. 629-649.

Rupel-Prevolnik, V. and Ogorevc, M. (2010), "Long-term care system in Slovenia”, Enepri research report no. 87. ANCIEN.

Schulz, E. (2010a), "The Long-Term care system for the elderly in Denmark”, Enepri research report no. 73. ANCIEN.

Schulz, E. (2010b), "The Long-Term care system for the elderly in Germany”, Enepri research report no. 78. ANCIEN.

Seekins, T., Traci, M.A., Cummings, S., Oreskovich, J. and Ravesloot, C. (2008), "Assessing environmental factors that affect disability: establishing a baseline of visitability in a rural state", Rehabilitation Psychology, Vol. 53 No. 1, pp. 80-84.

Shiller, R.J. (2005), Irrational Exuberance, Princeton, NJ, available at: www.irrationalexuberance.com 
Shiller, R.J. (2015), Irrational Exuberance, 3rd ed., Princeton University Press.

Soaita, A.M., Searle, B.A., McKee, K. and Moore, T. (2017), "Becoming a landlord: strategies of propertybased welfare in the private rental sector in Great Britain", Housing Studies, Vol. 32 No. 5, pp. 613-637.

Spasova, S., Baeten, R., Coster, S., Ghailani, D., Peña-Casas, R. and Vanhercke, B. (2018), Challenges in Long-Term Care in Europe: A Study of National Policies, European Commission.

Szander, N., Ros McDonnell, L. and Bogataj, M. (2017), "Prostorska razpršenost stanovanjskih enot kot pomemben dejavnik vpliva na stroške dolgotrajne oskrbe = spatial dispersion of housing units as an important factor influencing long-term care operational costs”, Urbani Izziv, Vol. 28 No. 1, pp. 67-76.147-156.

Temple, A., Andel, R. and Dobbs, D. (2010), "Setting of care modifies risk of nursing home placement for older adults with dementia", International Journal of Geriatric Psychiatry, Vol. 25 No. 3, pp. 275-281, doi: 10.1002/gps.2333.

Temple, A., Dobbs, D. and Andel, R. (2009), "Exploring correlates of turnover among nursing assistants in the National Nursing Home Survey", Health Care Management Review, Vol. 34 No. 2, pp. 182-90, doi: 10.1097/HMR.0b013e31819c8b11.

Torgersen, U. (1987), "Housing: the wobbly pillar under the welfare state", Scandinavian Housing and Planning Research, Vol. 4 No. sup1, pp. 116-127.

Ujvari, K. (2012), Long-Term Care Insurance 2012, Update, AARP Public Policy Institute, Washington, DC.

United Nations (2006), Convention on the Rights of Persons with Disabilities (CRPD). UN_Disabilitie, Department of Economics and Social Affairs, Geneva.

Wang, L., Valdez, E.A. and Piggott, J. (2008), "Securitization of longevity risk in reverse mortgages", North American Actuarial Journal, Vol. 12 No. 4, pp. 345-371.

Ward, M. and Franz, J. (2015), "The provision of visitable housing in australia: down to the detail", Social Inclusion, Vol. 3 No. 2, pp. 31-43, doi: 10.17645/si.v3i2.57.

Wood, C. (2017), "The social value of sheltered housing”, DEMOS Found 1. September 2017, available at: www.demos.co.uk/project/sheltered-housing/

Yang, S.S. and Wang, C.-W. (2013), "Pricing and securitization of multi-country longevity risk with mortality dependence", Insurance: Mathematics and Economics, Vol. 52 No. 2, pp. 157-169.

\section{Further reading}

Bogataj, D. and Aver, B. (2013), "Residential real estate investments from the perspective of the act on social security benefits”, Dignitas 2013(57-58), pp. 252-276.

Bae, G.I., Kim, W.C. and Mulvey, J.M. (2014), "Dynamic asset al.location for various financial markets under regime switching framework", European Journal of Operational Research, Vol. 234 No. 2, pp. 450-458.

Di Giacinto, M. and Vigna, E. (2012), "On the Sub-optimality cost of immediate annuitization in DC pension funds", Central European Journal of Operations Research, Vol. 20 No. 3, pp. 497-527.

Drobne, S. and Bogataj, M. (2012), "A method to define the number of functional regions: an application to NUTS 2 and NUTS 3 levels in Slovenia”, Geodetski Vestnik, Vol. 56 No. 1, pp. 105-150, ISSN 0351-0271.

Drobne, S. and Bogataj, M. (2017), "The impact of public investments in facilities on the potential housing market for older persons", Facilities, Vol. 35 Nos 7/8, pp. 422-435.

European Commission (2014a), "Adequate social protection for long-term care needs in an ageing society", Found 18. April 2018, available at: http://ec.europa.eu/social/main.jsp?catId=738\& langId=en\&pubId $=7724$ 
European Commission (2014b), "Operativni program za izvajanje evropske kohezijske politike v obdobju 2014-2020”, Found 8. May 2018, available at: www.eu-skladi.si/kohezija-do-2013/ ostalo/operativni-programi

European Commission (2015c), Special Eurobarometer 283: Health and long term care in the European Union, European Union, Found 11. May 2018 available at: http://ec.europa.eu/public_opinion/ archives/eb_special_300_280_en.htm\#283

Evropska komisija (2015b), The 2015 Ageing Report. Economic and budgetary projections for the 28 EU Member States (2013-2060). Found on 18. April 2016, available at: www.ec.europe.eu/ ecomoy_finance/publications/european_economy/ageing_report/index_en.htm

Fukushima, N., Adami, J. and Palme, M. (2010), “The long-term care system for the elderly in Sweden”, Enepri research report no. 89. ANCIEN.

Golinowska, S. (2010), "The Long-Term care system for the elderly in Poland”, Enepri research report no. 83. ANCIEN.

Haehling von Lanzenauer, C. and Wright, D.D. (1991), "Operational research and insurance”, European Journal of Operational Research, Vol. 55 No. 1, pp. 1-13.

Han, N-W. and Hung, M-W. (2012), "Optimal asset al.location for DC pension plans under inflation", Insurance: Mathematics and Economics, Vol. 51 No. 1, pp. 172-181.

Inštitut (2014), RS za socialno varstvo. "Analiza organiziranosti in izvajanje oskrbe na področju oskrbovanih stanovanj”.

Joël, M.E., Dufour-Kippelen, S., Duchêne, C. and Marmier, M. (2010), “The long-term care system for the elderly in France", Enepri research report no. 77. ANCIEN.

Johansson, E. (2010), “The long-term care system for the elderly in Finland”, Enepri research report no. 76. ANCIEN.

Kalache, A., Plouffe, L., et al. (2007), Global Age Friendly Cities Guide, WHO Press, Geneva. Found 1. September 2017, available at: www.who.int/ageing/publications

Kavšek, M. and Bogataj, D. (2016), "Ageing in place driving urban transformations", Journal of Universal Excellence, Vol. 5 No. 1, pp. 1-12.

Markowitz, H. (1952), "Portfolio selection”, The Journal of Finance, Vol. 7 No. 1, pp. 77-91.

Mincheva, L. and Kanazireva, G. (2010), "The Long-Term care system for the elderly in Bulgaria", Enepri research report no. 71. ANCIEN.

Ministrstvo za okolje in prostor, direktorat za prostor, graditev in stanovanja (2015), "Nacionalni stanovanjski program 2015-2025”, Javna in medresorska obravnava februar 2015.

Nagode, M. Lebar, L. Kovač, N. and Vidrih, N. (2016), "Inštitut RS za socialno varstvo (IRSSV)", Izvajanje pomoči na domu, Analiza stanja v letu 2015, Found 17. August 2017, available at: www.irssv.si/upload2/Izvajanje \%20PND \%20za \%20leto \%202015.pdf

PARA - Re-Form Associates Progressive Accessibility (2006), "Community building through visitable and adaptable housing", Gov. Mb. Canada. Found 1. September 2017, available at: www.gov.mb.ca/housing/mh/progs/pdf/visitable-housing-visitable-housing-communitybuilding.pdf

Prettner, K. and Prkawetz, A. (2010), "Demographic change in models of endogenous",

Roy, A.D. (1952), "Safety first and the holding of assets", Econometrica, Vol. 20 No. 3, pp. 431-449.

Skupnost socialnih zavodov Slovenije (2017), "Pregled prošenj in prostih mest v domovih za starejše in posebnih socialno-varstvenih zavodih", Found 17. August 2017, available at: www.ssz-slo.si/

Tediosi, F. and Gabriele, S. (2010), "The Long-Term care system for the elderly in Italy", Enepri research report no. 80. ANCIEN.

Tu, J. and Zhou, G. (2011), "Markowitz meets Talmud: a combination of sophisticated and naive diversification strategies", Journal of Financial Economics, Vol. 99 No. 1, pp. 204-215. 
UK Parlament (2017), "Future of supported housing inquiry", Found 1. September 2017, available at: www.parliament.uk/business/committees/committees-a-z/commons-select/work-andpensionscommittee/news-parliament-2015/future-of-supported-housing-launch-16-17/

Wu, D., Yang, Z., Vela, S. and Liang, L. (2007), "Simultaneous analysis of production and investment performance of Canadian life and health insurance companies using data envelopment analysis", Computers and Operations Research, Vol. 34 No. 1, pp. 180-198.

Zavod za zdravstveno zavarovanje Slovenije (ZZZS) (2017), "Actual data of nursing homes residents", Data was provided by National Health Institute of Slovenia.

\section{Corresponding author}

David Bogataj can be contacted at: dbogataj@actuary.si

For instructions on how to order reprints of this article, please visit our website: www.emeraldgrouppublishing.com/licensing/reprints.htm

Or contact us for further details: permissions@emeraldinsight.com 